Research Article, Issue 3
Analytical Methods in Environmental Chemistry Journal
AMECJ

\title{
A Review: Water pollution by heavy metal and organic pollutants: Brief review of sources, effects and progress on remediation with aquatic plants
}

\author{
Isiuku Beniah Obinnaa and Enyoh Christian Ebere ${ }^{\text {a,* }}$
}

a,* Department of Chemistry, Imo State University, Imo State, Nigeria

A R T I C L E I N F O:

Received 20 Jun 2019

Revised form 25 Jul 2019

Accepted 6 Aug 2019

Available online 24 Sep 2019

Keywords:

Chemical pollutants,

Chemometrics,

Constructed wetlands,

Hydroponics,

Macrophytes,

Models, Toxicity,

Water pollution

\begin{abstract}
A B S T R A C T
Heavy metals and organic pollutants are ubiquitous environmental pollutants affecting the quality of soil, water and air. Over the past 5 decades, a lot of strategies have been being developed for treatment of polluted water. Strategies involving aquatic plant use are preferable to conventional methods. In this study, an attempt was made to provide a profound and brief review on latest and newest progresses in research and practical applications of phytoremediation for water resources with the following objectives: (1) to discuss the toxicity of chemicals pollution in water to plant, animals, and human health (2) to summarise the physicochemical factors affecting removal of toxic chemicals such as heavy metals and organic contaminants in aqueous solutions by aquatic plants; (3) to summarise and compare the removal rates of heavy metals and organic contaminants in aqueous solutions by diverse aquatic plants; and (4) to summarise chemometric models for testing aquatic plant performance. More than 20 aquatic plants specie have been used extensively while duckweed (L. minor), water hyacinth (Eichhornia crassipes), water lettuce (P. stratiotes) are the most common. Overall, chemometrics for performance assessment reported include: Growth rate (GR), Growth rate inhibition (\% Inhibition), Metal uptake (MU), translocation/ transfer factor (TF), bioconcentration factor (BCF), Percent metal uptake (\% MU), Removal capacity (RC) and Tolerance index (TI) while absorption rate have been studied using the sorption kinetics and isotherms models such as pseudo-first-order (PFO), pseudo-second-order (PSO), Freundlich, Langmuir and Temkin. Using modeling and interpretation of adsorption isotherms for performance assessment is particularly good and increases level of accuracy obtained from adsorption processes of contaminant on plant. Conclusion was drawn by emphesizing the gap in knowledge and suggesting very important future areas of research for scientists and policymakers.
\end{abstract}

\section{Introduction}

One precious natural resource is water, which is relied on for agricultural sustainability and mankind civilization. Water covers over $70 \%$ of the earth crust and majority of the water have been subjected to maximum exploitation and severely degraded or polluted because of anthropogenic activities. Often times, water resources (including surface water and groundwater) even though they are interrelated and connected, are sperately

\footnotetext{
${ }^{*}$ Corresponding Author: Enyoh Christian Ebere Email: cenyoh@gmail.com

https://doi.org/10.24200/amecj.v2.i03.66
}

managed and studied [1]. Surface water seeps through the soil and becomes groundwater and vice versa. Therefore, both surface and groundwater sources maybe contaiminated by similar pollution sources. Pollution sources may include point (from a single, identifiable source) and non-point (many sources) sources. Irrespective of the contamination source, damaging effects are still made to the ecosystem; especially those sources that add heavy metals or organic pollutants to waters because they are persistent in the environment and have been associated with mutagenic, teratogenic and carcinogenic effects. These pollutants cannot be easily destroyed biologically but are often 
transformed from one oxidation state or organic complex to another [2-3], thus remaining in the environment for a very longtime. Therefore, toxic chemical pollution of water poses a great threat to the ecosystem. Many technologies that are easy to use have been developed as part of the continuous efforts to make water free from contamination, be of good quality, sustainable and economically feasible. Approaches involving chemical extraction, chemical isolation and containment, thermal method, chemical redox process, and electrokinetics have been widely used, especially at a small scale while difficult to use at large scale due to high costs and side effects [4]. Therefore, the search for an alternative clean and cheap technique for water cleaning became important. Plants use in treating contaminatedwater was proposed about 300 years ago, as an emerging cheaper technology [5]. Over the years, the concept has gained increasing attention and has been adopted by scientist, governmental and non-governmental organizations. Many studies regarding plant use for environment clean-up has focused on contaminated soils while regarding water medium have been less studied. Many aquatic plant species have been identified and tested for removing heavy metals and organic pollutants in water [4]. Mechanisms of uptake by whole plant as well as remediation performance studied using chemometrics have been done. There are progresses made over the years using hydroponics or field experiment. They were reviewed and reported in this paper.

\section{Methodology}

This research was carried out through a collection of data and information from scientific articles regarding the potential of some aquatic plants for phytoremediation of toxic chemicals such as heavy metals (specifically: $\mathrm{As}, \mathrm{Cu}, \mathrm{Cr}, \mathrm{Hg}, \mathrm{Cd}, \mathrm{Ni}, \mathrm{Pb}$ and $\mathrm{Zn}$ ) and organic pollutants. The scientific articles were sought majorly from Google scholar and back searches through references. For an article to be included, it must be published in year 2000 and above, in order to ensure that current information was provided. However, few selected articles prior to 2000 included were due to their importance in the initial set of empirical studies.

\section{Water pollution}

All life forms on earth depend on water for their presence in the ecosystem. According to [6], water is the second most important element required by human for survival after the air we breathe. The quality of water globally has been affected negatively due to man-made activities including unskilled utilization of natural water resources. Even though, the United Nations recognizes the availability of good drinking water for humans as a human right, considerable numbers of people worldwide are still suffering with the absence of clean and new drinking water. Over 900 million people out of the 7.7 billion people currently in the world, lack access to enhanced drinking water. A value which present a significance decrease from around 2.6 billion peoples in 1990 and approximately 600 billion people expected in 2015 if the United Nations' Millennium Development Goal was achieved having access to enhanced drinking water $[7,8]$. Furthermore, World Water Council estimated that around 3.9 billion people by 2030 will be living in water scare areas [9]. In Nigeria, irrespective of the total replenishable water resource estimated at 319 billion cubic meters, only $58 \%$ and $39 \%$ of the inhabitants in urban and rural areas have access to potable water supply respectively [10]. Whilst there is an increase in urbanization, industrialization and population, the demand for water assets is expanding daily and thereby leading to serious contamination of surface and ground water. The chief sources of water pollution are presented in Table 1 and 5 . Marine pollution and nutrient pollution are the two types of surface water pollution. The former involves introduction of toxic substances (such as toxic metals, pharmaceuticals, pesticides, dyes, and surfactants) while the later refers to contamination by excessive inputs of nutrients, which is primarily responsible for eutrophication of surface waters. It is considerable that $70-80 \%$ of all well-known problems in developing countries are identified 
with water pollution, especially for children. The toxic pollutants released in wastewaters can be detrimental to aquatic organisms which also cause the regular waters to be unfit as consumable water sources [11-14]. Studies have implicated water pollution as the leading cause of death and diseases worldwide [15-16]. In 2015, water pollution caused the deaths of 1.8 million people [17]. Thereby, making water pollution a global concern, which requires continous assessment and revision of water resource policy at all levels (international down to individual aquifers and wells).

\subsection{Heavy metals}

Metals with high density $\left(\geq 5 \mathrm{~g} / \mathrm{cm}^{-3}\right)$ are often regarded as heavy metals. They are ubiquitous in nature and adversely affect the environment and living organisms [18]. The levels and compositions of heavy metal are often determined and controlled/ influenced by local activities [19-21] while those ones suspended in air is monitored by the metal properties and various environmental factors [22] such as precipitation, rainfall and wind etc. Water (surface and ground) pollution by heavy metals is a global issue. Many surface and ground water in many countries (if not all) of the world have been affected by heavy metal pollution, but the severity of pollution vary enormously and controlled mainly by local activities. Many areas in Europe have been reported to be greatly affected by heavy metals [23] while in the USA, government statistics revealed that more than $19000 \mathrm{~km}$ of US streams and rivers have been contaminated by heavy metals from coal mine and acid mine drainage $[24,25]$. In Asia, some countries such as India, Pakistan and Bangladesh are experiencing severe pollution of surface water due to untreated effluents being poured in surface drains by small industrial units and from the use of raw sewage in producing vegetables near big cities, which ends in surface water by runoff and groundwater by leaching processes [25]. Generally, heavy metals identified in the polluted rivers in Asia include $\mathrm{As}, \mathrm{Cu}, \mathrm{Cd}, \mathrm{Pb}, \mathrm{Cr}, \mathrm{Ni}, \mathrm{Hg}$ and $\mathrm{Zn}$. In different parts of Africa including North, East, South and West Africa, there are reports on heavy metal (notably $\mathrm{Pb}, \mathrm{Cd}, \mathrm{Hg}, \mathrm{Cu}, \mathrm{Co}, \mathrm{Zn}, \mathrm{Cr}, \mathrm{Ni}, \mathrm{Mn}, \mathrm{Fe}$, As and $\mathrm{V}$ ) concentrations in surface water exceeding recommended limits, thereby polluting the surface waters in the region [26]. In Nigeria alone out of inland freshwater system estimated to be about $283,293.47$ hectares, only about $84,988.041$ is still useful due to pollution [21]. In West Africa, najor pollution source is peteroleum-related activities including frequent acts of sabotage to oil facilities [21,26]. In Northern Africa, the contribution of agricultural activities (use of phosphate fertilizers and pesticides), East Africa include indiscriminate dumping of waste while in Southern Africa, mining activities are the major sources of environmental pollution [26]. Literatures reveal that natural rock weathering or geogenic sources and anthropogenic sources (man-made based from emission or effluent from the use of products containing heavy metals or capable of absorbing metals) are two broad sources for heavy metals introduction into the environment [20, 27-29]. The summary of sources of various heavy metals is listed in Table 1 while the consumption related emissions are presented in Table 2. The intensity of pollution is ontrolled by local activities; high anthropogenic activities may cause high heavy metal pollution. Generally urban waterbodies have higher heavy metals' concentrations in comparison with less urbanized areas. However, in Europe the emission of some metals is decreasing perhaps due to increase in use of clean(er) technologies, improvements in emission controls and phasing out of leaded petrol, following the 1998 Heavy Metals Protocol enforced by 29 December 2003. The trend of emission of selected heavy metals between the years 1990 to 2016 is presented in Figure 1. The emissions of $\mathrm{Cd}, \mathrm{Hg}$ and $\mathrm{Pb}$ have declined by approximately $35 \%, 30 \%$ and $10 \%$ respectively since 1990 [30]. Furthermore, other priority heavy metals emissions such as As, $\mathrm{Cu}, \mathrm{Ni}$ and $\mathrm{Zn}$ is simultaneously reduced by $57 \%$, $53 \%, 65 \%$ and $29 \%$, respectively [31].

\subsubsection{Effects of heavy metals pollution of water}

Many previous studies have extensively reviewed the adverse effects of heavy metals to human 
Table 1. Different sources of some heavy metals

\begin{tabular}{ll}
\hline Heavy metals (HM) & Sources \\
\hline As & $\begin{array}{l}\text { Semiconductors, petroleum refining, wood preservatives, animal feed additives, coal power } \\
\text { plants, herbicides, volcanoes, mining and smelting }\end{array}$ \\
Gd & $\begin{array}{l}\text { Geogenic sources, anthropogenic activities, metal smelting and refining, fossil fuel burning, } \\
\text { application of phosphate fertilizers, sewage sludge }\end{array}$ \\
$\mathbf{C r}$ & Electroplating industry, sludge, solid waste, tanneries \\
$\mathbf{C u}$ & Electroplating industry, smelting and refining, mining, biosolids \\
$\mathbf{H g}$ & Volcano eruptions, forest fire, emissions from industries producing caustic soda, coal, peat \\
$\mathbf{N i}$ & and wood burning \\
$\mathbf{P b}$ & Volcanic eruptions, land fill, forest fire, bubble bursting and gas exchange in ocean, \\
& weathering of soils and geological materials \\
$\mathbf{Z n}$ & Mining and smelting of metalliferous ores, burning of leaded gasoline, municipal sewage, \\
$\mathrm{Sou}$ & industrial wastes enriched in Pb, paints \\
Electroplating industry, smelting and refining, mining, biosolids
\end{tabular}

Source: [25].

Table 2. Consumption-related emissions factors ( $\mathrm{ppm}$ ) of heavy metals

\begin{tabular}{|c|c|c|c|c|c|c|c|c|c|c|c|}
\hline HM & $\begin{array}{c}\text { Metallic } \\
\text { use }^{\mathrm{a}}\end{array}$ & $\begin{array}{c}\text { Plating } \\
\text { and } \\
\text { coating }\end{array}$ & $\begin{array}{c}\text { Paint } \\
\text { pigments }\end{array}$ & $\begin{array}{c}\text { Electron } \\
\text { tubes and } \\
\text { batteries }^{\mathrm{d}}\end{array}$ & $\begin{array}{c}\begin{array}{c}\text { Other } \\
\text { electrical } \\
\text { equipment }\end{array} \\
\end{array}$ & $\begin{array}{c}\text { Chemical } \\
\text { uses, not } \\
\text { embodied }^{\mathrm{f}}\end{array}$ & $\begin{array}{c}\text { Chemica } \\
\text { uses, } \\
\text { embodied }^{\text {g }}\end{array}$ & $\begin{array}{c}\text { Agricultural } \\
\text { uses }^{\text {h }}\end{array}$ & $\begin{array}{c}\text { Non- } \\
\text { agricultural } \\
\text { uses }^{\mathrm{i}}\end{array}$ & $\begin{array}{c}\text { Medical } \\
\text { and } \\
\text { dental } \\
\end{array}$ & $\begin{array}{l}\text { Misc. } \\
\text { NEC }\end{array}$ \\
\hline As & 0.001 & 0 & 0.5 & 0.01 & NA & NA & 0.05 & 0.50 & 0.8 & 0.8 & 0.15 \\
\hline Cd & 0.001 & 0.15 & 0.5 & 0.02 & NA & 1 & 0.15 & NA & NA & NA & 0.15 \\
\hline $\mathrm{Cr}$ & 0.001 & 0.02 & 0.5 & NA & NA & 1 & 0.05 & NA & 1 & 0.8 & 0.15 \\
\hline $\mathrm{Cu}$ & 0.005 & 0 & 1.0 & NA & 0.10 & 1 & 0.05 & 0.05 & 1 & NA & 0.15 \\
\hline $\mathrm{Hg}$ & 0.050 & 0.05 & 0.8 & 0.20 & NA & 1 & NA & 0.80 & 0.9 & 0.2 & 0.50 \\
\hline $\mathbf{P b}$ & 0.005 & 0 & 0.5 & 0.01 & NA & 1 & 0.75 & 0.05 & 0.1 & NA & 0.15 \\
\hline $\mathbf{Z n}$ & 0.001 & 0.02 & 0.5 & 0.01 & NA & 1 & 0.15 & 0.05 & 0.1 & 0.8 & 0.15 \\
\hline
\end{tabular}

NA- Not available primarily to wear and corrosion, except for mercury which volatilizes.

b. Protective surfaces deposited by dip coating (e.g. galvanizing, electroplating vacuum deposition, or chemical bath (e.g. chromic acid).Losses in use are mainly due to wear and abrasion (e.g. silverplate), or flaking (decorative chrome trim). In the case of mercury-tin "silver" for mirrors, losses were largely due to volatilization.

c. Paints and pigments are lost primarily by weathering (e.g. for metal-protecting paints), by wear, or by disposal of painted dyes or pigmented objects, such as magazines. Copper-and mercury-based paints slowly volatilize over time. A factor of 0.5 is rather arbitrarily assumed for all other paints and pigments.

d. Includes all metals and chemicals (e.g. phosphorus) in tubes and primary and secondary batteries, but excludes copper wire. Losses in manufacturing may be significant. Mercury in mercury vapour lamps can escape to the air when tubes are broken. In all other cases it is assumed that discarded equipment goes mainly to landfills. Minor amounts are volatilized in fires or incinerators or lost by corrosion; lead-acid batteries are recycled.

e. Includes solders, contacts, semiconductors and other special materials (but not copper wire) used in electrical equipment control devices and instruments, etc. Losses to the environment are primarily via discard of obsolete equipment to landfills. Mercury used in instruments is lost via breakage and volatilization or spillage.

f. Chemical uses not embodied in final products include catalysts, solvents, reagents, bleaches, etc. In some cases a chemical is basically embodied but there are some losses in processing. Losses in chemical manufacturing per se are included here. Major examples include copper and mercury catalysts (especially in chloride $\mathrm{mfg}$ ); copper, zinc and chromium as mordants for dyes; mercury losses in felt manufacturing; chromium losses in tanning; lead in desulphurization of gasoline; zinc in rayon spinning, etc. In some cases virtually all of the material is actually dissipated. We include detonators such as mercury fulminate and lead azide (and explosives) in this category.

g. Chemical uses embodied in final products other than paints or batteries include fuel additives (e.g. TEL). anti-corrosion agents (e.g. zinc dithiophosphate), initiators and plasticizers for plastics (e.g. zinc oxide), etc. Also included are wood preservatives and chromium salts embodied in leather. Losses to the environment occur when the embodying productivity is utilized, for example gasoline containing TEL is burned and largely dispersed into the atmosphere. However, copper, chromium, and arsenic are used as wood preservatives and dispersed only if the wood is later burned or incinerated.

h. Agricultural pesticides, herbicides, and fungicides. Uses are dissipative but heavy metals are largely immobilized by soil. Arsenic and mercury are exceptions because of their volatility.

i. Non-agricultural biocides are the same compounds, used in industrial, commercial, or residential applications. Loss rates are high in some cases. j. Medical/dental uses are primarily pharmaceutical (including cosmetics) germicides, also dental filling material. Most are dissipated to the environment via waste water. Silver and mercury dental fillings are likely to be buried with the dead body

Source: [32] 


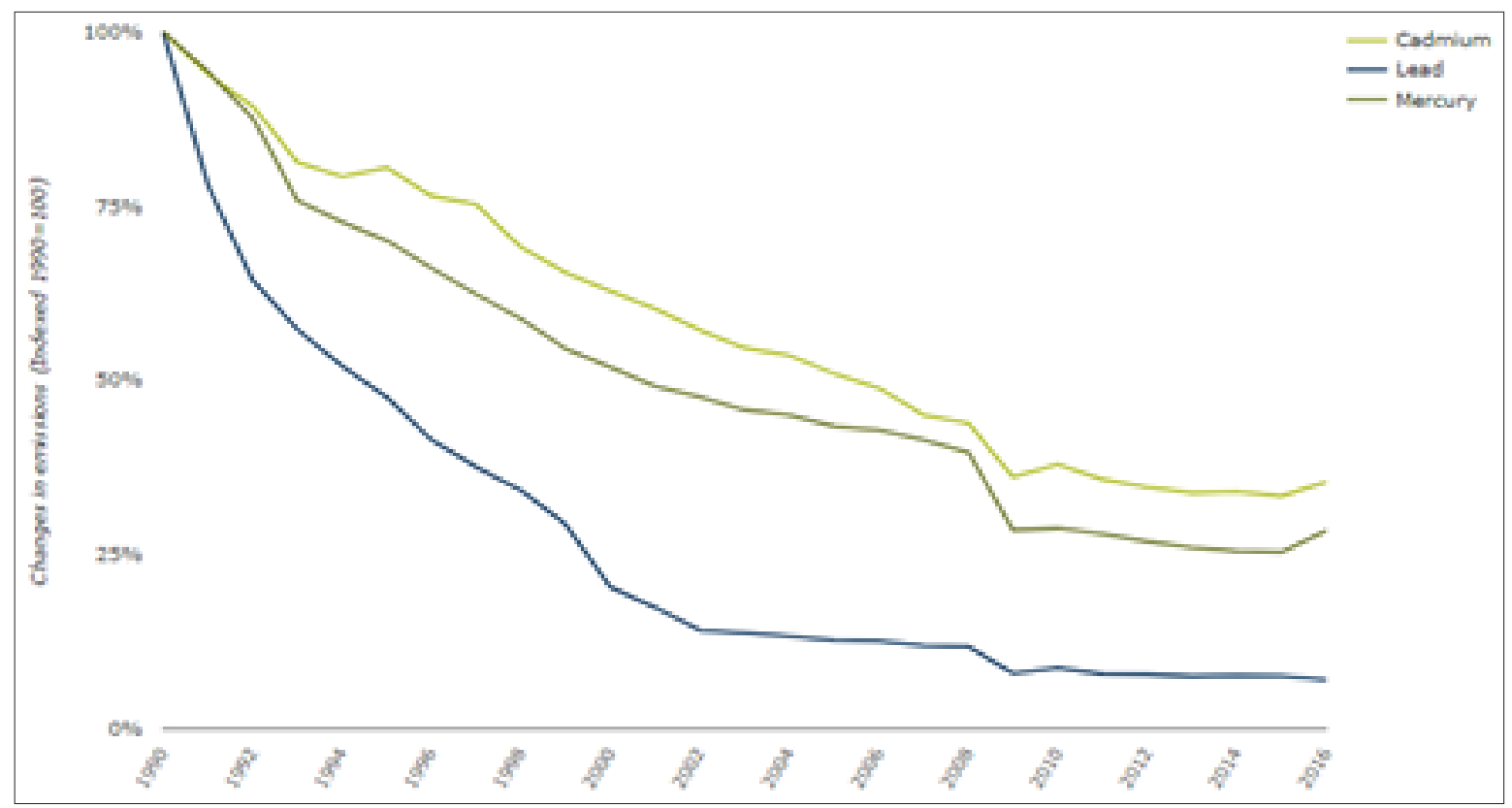

Fig. 1. Trends in emissions of heavy metals from 1990 to 2016 (Source: [30])

and ecological system [14, 18, 33-36]. Increased levels of heavy metal contaminants in water affect negatively the ecological function of water including recycling and primary production of nutrients. Also affected is the health of wildlife and humans through bioaccumulation in the food chain with the lasting impact of metal tolerance development among certain organisms. Furthermore, harmful ecological impacts of metals may include info-disruption, that impact intra and interspecies interaction among freshwater organisms and microbes [21]. However, the effects of heavy metal pollution in water shall be discussed under the following; plants, aquatic animals and humans. The toxicity of heavy metals to aquatic plant, animal and human is depended on the solubility and bioavailability of the metals, organism tolerance, $\mathrm{pH}$, and presence of other ions that interfere with bioavailability, among other issues that may interfere with the result of contact with the element [37].

\subsubsection{Plant}

Some heavy metals are needed for upkeep and growth by aquatic plants. However, when the concentrations become excessive, the plant may be at risks of heavy metal toxicity both directly and indirectly. High concentrations of heavy metals in plant may interfere with metabolic functions, including physiological and biochemical processes such as oxidative stress from production of reactive oxygen species (ROS), inhibition of photosynthesis, and respiration and degeneration of main cell organelles, even leading to death of plants [2, 38-39]. Other specific effects include growth reduction (especially the origin and main part of system is more affected), chlorosis and leaf necrosis followed by traces of senescence and abscission, which changes lead to lower nutrient uptake and interfere with the biomass acquired [40]. A visual symptom of metal toxicity to plant is presented in Figure 2.

The effect of heavy metal toxicity on the aquatic plants varies according to the particular heavy metal involved in the process, multi-metal interaction in the water and the plant itself. In terms of particular heavy metal, exposure of Water hyacinth (Eichhornia crassipes) to excess arsenic (As) concentration of $6 \mathrm{mg} / \mathrm{L}$ over $\geq 8$ days lead to the death of the plant while the plant became unhealthy after 3 days of exposure [42]. At the same concentration of $6 \mathrm{mg} / \mathrm{L}$ and a different concentration of $2.5 \mathrm{mg} / \mathrm{L}$, Eichhornia crassipes was able to withstand zinc (II) and cadmium (II) sorption respectively in water [43]. Furthermore, in 
A

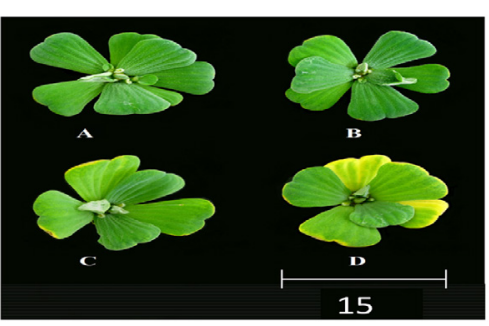

B

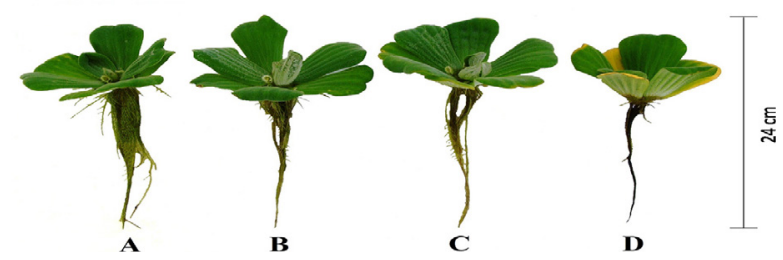

Fig. 2. Visual symptoms of arsenic toxicity in leaves (A) and roots (B) of Pistia stratiotes exposed to three As ${ }^{\text {III }}$ concentrations after four days (reprinted from [41]).

terms of plant, Brake fern (Pteris vita) accumulated As up to concentration of $7500 \mathrm{mg} / \mathrm{kg}$ without showing symptom of toxicity [44] while Water hyacinth (Eichhornia crassipes) survives at that concentration. Literature reveals that adverse effects have been observed in aquatic plants for $\mathrm{Pb}, \mathrm{Cd}, \mathrm{Hg}$, and $\mathrm{As}$ at very low concentration in the growth medium. Also, effects maybe enhanced or reduced by the combination or presence of many metals in the media. Wiafe [45] observed that the level of uptake of metals (As, $\mathrm{Hg}, \mathrm{Cd}$ and $\mathrm{Pb}$ ) by Typha capensis was inhibited when either two of the heavy metals existed in the solution. Some plants tolerate or counteract the damages of heavy metals while some at certain concentration increase in nutrient and size. For example, when $E$. camaldulensis species was exposed to $45 \mu \mathrm{mol} / \mathrm{L}$ $\mathrm{Cd}$, an increase of carotenoids (related to the tolerance to oxidative stress), epidermis and root endoderm thickness was obseverd [37, 51]. The tolerance could be due to some phyto-compounds such as anthocyanins, thiols, and antioxidant scavenging enzymes [52]. Furthermore, at 50 $\mathrm{mg} / \mathrm{kg}$ of $\mathrm{Co}$, there was an increase in nutrient content of tomato plants [53] and increase in plant growth, nutrient content, biochemical content, and antioxidant enzyme activities (catalase) in radish and mung bean [54, 55]. Over 14 days exposure of Ipomonea aquatica (water spinach) to high $\mathrm{Cr}^{3+}$ $\left(10 \mathrm{mg} \mathrm{L}^{-1}\right)$ in contaminated water (in hydroponic system), the root of the plant increased in size (becoming fatter) rather than longer [50]. Some aquatic plants have the tendency to recover within days after exposure to high concentration of heavy metals. For instance, Drost et al., [56] observed that after high exposure to copper, nickel and cadmium toxicity, Duckweed recovered within days. It is safe to state where plant survives a high level of exposure to a toxicant or stress, there is a potential for full recovery [57].

\subsubsection{Aquatic animals}

One major biomarker of heavy metal toxicity in aquatic environment is fish. Although, they are of great importance economically, they are greatlty affected by heavy metals. Exposure of fish species to heavy metals may be from contact directly or from food web or chain indirectly. Long term exposure can cause death to juvenile fish and reduced breeding potential of adults fish as indicated in many reports [58-61]. The toxicity may cause structural changes in the organs at microscopic cellular, DNA, chronic stress and organ level leads to alterations of the function systems and eventual growth inhibition [62]. In fish system, highest concentration of heavy metals was reported to be in the kidney and liver [63]. Creatures in benthic environment, such as worms, crustaceans and insects are greatly by contaminated sediment by heavy metals, affecting their feeding habit and eventual death and reducing the food availability for larger animals such as fish [64].

\subsubsection{Human health}

In water, metals are present as complex mixtures of discrete mineral phases. However, bioavailability of metals (determined through metal speciations) determines the impacts on human health. Several studies have explored routes of exposure from water which include dermal contact and the most direct exposure pathway including oral ingestion [6,10,13,27-28,65-66]. Adverse health impacts to human health are mainly controlled by concentrations (amount) ingested and individuals (with compromised metabolism and poor clearance 
Table 3. Effect of heavy metal toxicity on some aquatic plants

\begin{tabular}{|c|c|c|c|}
\hline Metal & Aquatic Plant & Toxic effect & References \\
\hline Al & $\begin{array}{l}\text { Duckweed } \\
\text { (Lemna minor L.) }\end{array}$ & $\begin{array}{l}\text { Decline in enzymatic activity, reduced efficiency of } \\
\text { photosynthetic energy conversion }\end{array}$ & {$[46]$} \\
\hline \multirow[t]{3}{*}{ As } & $\begin{array}{l}\text { Water hyacinth } \\
\text { (Eichhornia crassipes) }\end{array}$ & Stunted growth, chlorosis, wilting, death & [42] \\
\hline & $\begin{array}{l}\text { Water lettuce } \\
\text { (Pistia stratiotes L.) }\end{array}$ & $\begin{array}{l}\text { Sharp reduction in the root volume, chlorosis, organ also } \\
\text { became darker, cell membrane damage, reduction in relative } \\
\text { growth rate; reduced photosynthetic } \mathrm{O}_{2} \text { evolution activity, high } \\
\text { enzyme activitysuch as superoxide dismutase (SOD), catalase } \\
\text { (CAT), peroxidase (POX) and ascorbate peroxidase (APX) }\end{array}$ & [41] \\
\hline & Brake fern (Pteris vita) & $\begin{array}{l}\text { Decline in enzymatic activity, reduced efficiency of } \\
\text { photosynthetic energy conversion }\end{array}$ & [44] \\
\hline \multirow[t]{5}{*}{ Cd } & $\begin{array}{l}\text { Duckweed } \\
\text { (Lemna minor L.) }\end{array}$ & Reduced shoot growth; inhibition of root growth & [47] \\
\hline & $\begin{array}{l}\text { Iridaceae (Gladiolous), } \\
\text { Isoetaceae (Isoetes }\end{array}$ & Reduced shoot growth; inhibition of root growth & [48] \\
\hline & $\begin{array}{l}\text { taiwaneneses D.) and Amazon } \\
\text { sword plant or burhead } \\
\text { (Echinodorus Amazonicus) }\end{array}$ & & \\
\hline & $\begin{array}{l}\text { Water hyacinth } \\
\text { (Eichhornia crassipes) }\end{array}$ & $\begin{array}{l}\text { Stunted growth, plant height and root length decreased, } \\
\text { chlorosis }\end{array}$ & [49] \\
\hline & $\begin{array}{l}\text { Water lettuce } \\
\text { (Pistia stratiotes L.) }\end{array}$ & $\begin{array}{l}\text { Stunted growth, plant height and root length decreased, } \\
\text { chlorosis }\end{array}$ & [49] \\
\hline $\mathrm{Cr}$ & $\begin{array}{l}\text { Water spinach } \\
\text { (Ipomonea aquatica) }\end{array}$ & Increased in root size, root length decreased & {$[50]$} \\
\hline \multirow[t]{3}{*}{$\mathbf{Z n}$} & $\begin{array}{l}\text { Duckweed } \\
\text { (Lemna minor L.) }\end{array}$ & $\begin{array}{l}\text { Decline in enzymatic activity, reduced efficiency of } \\
\text { photosynthetic energy conversion, decrease in chlorophyll }\end{array}$ & [46] \\
\hline & $\begin{array}{l}\text { Water hyacinth } \\
\text { (Eichhornia crassipes) }\end{array}$ & $\begin{array}{l}\text { Stunted growth, plant height and root length decreased, } \\
\text { chlorosis }\end{array}$ & [49] \\
\hline & $\begin{array}{l}\text { Water lettuce } \\
\text { (Pistia stratiotes L.) }\end{array}$ & $\begin{array}{l}\text { Stunted growth, plant height and root length decreased, } \\
\text { chlorosis }\end{array}$ & [49] \\
\hline
\end{tabular}

mechanisms) $[28,66]$. Generally, assessment of health risk of potentially toxic metals involves the quantitative assessment of the possibility of the deleterious impacts occurring in a given set of conditions [66]. Summary of selected heavy metal impacts on human health nand major biomarkers of importance is presented in Table 4.

\subsection{Organic pollutants}

Organic pollutants are pollutants that are organic in nature i.e basically containing carbon covalently bonded with other compounds. They are known to be toxic or carcinogenic in nature. Their presence in water in large quantity causes considerable and widespread concern. Rivers serves as hotspot for organic pollutant loading, particularly those in lowland regions [74].

Organic water pollutants generally include: detergents, disinfection by-products (having "down-the-drain" applications [221]), food processing waste, insecticides and herbicides, petroleum hydrocarbons and lubricants, and fuel combustion byproducts (from storm water runoff) [75], volatile organic compounds, chlorinated solvents, perchlorate (from personal care products), drug pollution (involving pharmaceutical drugs and their metabolites). Some of these organic water pollutants contain compounds that are persistent in nature and elicited most concern from the international community regarded as persistent organic pollutants (POPs). POPs are heterogeneous set of man-made compounds that 
Table 4. Human health effects of some heavy metals

\begin{tabular}{|c|c|c|c|}
\hline Metal & Effects & $\begin{array}{l}\text { Most common Biomarkers of } \\
\text { Exposure }\end{array}$ & References \\
\hline Cd & $\begin{array}{l}\text { Increased risk of osteoporosis, renal tubular, glomerular and lung } \\
\text { damage, by affecting cardiovascular, developmental, digestive, } \\
\text { nervous, urinary, reproductive, and respiratory (From the nose to } \\
\text { the lungs) systems. }\end{array}$ & $\begin{array}{l}\text { Blood, urine, feces, liver, } \\
\text { Kidney and Bone. }\end{array}$ & [67] \\
\hline $\mathrm{Cr}$ & $\begin{array}{l}\text { Causes allergic dermatitis, low birth weight and also affecting } \\
\text { immune, urinary, respiratory and cardiovascular systems. }\end{array}$ & Blood or urine & [68] \\
\hline Co & Nausea and vomiting Dermatitis. & Urine and Blood. & {$[69]$} \\
\hline $\mathbf{C u}$ & Liver and kidney damage, immunotoxic, and death. & Blood, urine, hair, and nails. & {$[70]$} \\
\hline $\mathbf{N i}$ & Dermatitis, allergicreaction and chronic bronchitis. & Blood, bone, and urine. & {$[71]$} \\
\hline $\mathbf{P b}$ & $\begin{array}{l}\text { Affects the central nervous system, impair neurodevelopment } \\
\text { in children, metabolic processes, renal, gastrointestinal, } \\
\text { ocular and musculoskeletal systems, thereby causing nausea } \\
\text {,anorexia, severe abdominal cramps, colic, weight loss, renal } \\
\text { tubular dysfunction, abortion, muscle and joint pains and strong } \\
\text { biochemical effect behavioral disorders, low intelligence, strokes. }\end{array}$ & Blood, bone, and urine. & [72] \\
\hline Zn & $\begin{array}{l}\text { Attacks digestive, haematological, and respiratory system and } \\
\text { causing anemia, pancreas damage, and decrease high density } \\
\text { lipoprotein (HDL) cholesterol. }\end{array}$ & $\begin{array}{l}\text { Serum zinc level. High } \\
\text { levels of zinc in feces or } \\
\text { urine are indicative of } \\
\text { recent exposure }\end{array}$ & [73] \\
\hline
\end{tabular}

are easily transported from their source and easily reconcentrated in the new environment to potential toxic or hazardous levels. Concern regarding the toxicities of these pollutants brought about a global treaty which is known as the Stockholm Convention, launched in 2001 to reduce drastically or eliminate POP release to the environment [76]. Many evidences exist regarding waterbodies pollution by organic pollutants. In drinking water, concentration rarely exceeds $20 \mathrm{mg} / \mathrm{L}^{-1}$ [74]. Some organic pollutants including polychlorinated dibenzo- $p$ dioxins and polychlorinated dibenzofurans (PCDD/ Fs), antibiotics, herbicides and bisphenol A (BPA), have drawn significant attention by environmental researchers [77, 227]. However, other organic pollutants considered low priority pollutants may be inform of nutrient or dissolved materials including phosphates, nitrate, sulphate, ammonium nitrate, nitrite etc. Major sources of specific classes of pollutant in water are summarized in Table 5 .

\subsubsection{Adverse effects of Organic pollutants in water}

Although microorganisms can degrade organic pollutant load in water through a self-purification process involving using of sufficient oxygen, dilution, sedimentation and sunlight. The adverse effect of organic pollutants in water sources shall be discussed briefly under the following headings; plant, aquatic animal and human.

\subsubsection{Plant}

Exposure of aquatic plants to organic pollutants is generally through uptake from roots influenced by their low volatility and through plant leaves by contact from air, often a consequence of agricultural spraying with organochemicals. After uptake by plants, organic pollutants are translocated to different parts of the plants, where toxicity may occur. Transport pathways in higher plants generally involves; short distance transport (intracellular and intercellular) and long distance transport (conducting tissue transport) [78]. However, some chemical based on their chemistry (e.g water-hating organic chemicals) are only limited in phloem [78-79]. Aquatic plant tolerance to uptake of organic pollutants seems to correlate with the ability to deposit large quantities of 
Table 5. Major sources of organic pollutants in water

\begin{tabular}{|c|c|}
\hline Chemical class & Sources \\
\hline $\begin{array}{l}\text { Aliphatic and aromatic } \\
\text { hydrocarbons (including } \\
\text { benzenes, phenols and } \\
\text { petroleum hydrocarbons) }\end{array}$ & $\begin{array}{l}\text { Petrochemical industry wastes, Heavy/fine chemicals industry wastes, Industrial } \\
\text { solvent wastes, Plastics, resins, synthetic fibres, rubbers and paints production, } \\
\text { Coke oven and coal gasification plant effluents, Urban run-off, Disposal of oil and } \\
\text { lubricating wastes }\end{array}$ \\
\hline $\begin{array}{l}\text { Polynuclear aromatic } \\
\text { hydrocarbons (PAHs) }\end{array}$ & $\begin{array}{l}\text { Urban run-off, Petrochemical industry wastes, Various high temperature pyrolytic } \\
\text { processes, Bitumen production, Electrolytic aluminium smelting, Coal-tar coated } \\
\text { distribution pipes }\end{array}$ \\
\hline $\begin{array}{l}\text { Halogenated aliphatic and } \\
\text { aromatic hydrocarbons }\end{array}$ & $\begin{array}{l}\text { Disinfection of water and waste water, Heavy/fine chemicals industry wastes, } \\
\text { Industrial solvent wastes and dry cleaning wastes, Plastics, resins, synthetic fibres, } \\
\text { rubbers and paints production, Heat-transfer agents, Aerosol propellants, Fumigants }\end{array}$ \\
\hline Organochlorine pesticides & $\begin{array}{l}\text { Agricultural run-off, Domestic usage, Pesticide production, Carpet mothproofing, } \\
\text { Timber treatment }\end{array}$ \\
\hline Polychlorinated biphenyls & $\begin{array}{l}\text { Capacitor and transformer manufacture, Disposal of hydraulic fluids and lubricants, } \\
\text { Waste carbonless copy paper recycling, Heat transfer fluids, Investment casting } \\
\text { industries PCB production }\end{array}$ \\
\hline Phthalate esters & $\begin{array}{l}\text { Plastics, resins, synthetic fibres, rubbers and paints production, Heavy/fine } \\
\text { chemicals industry wastes, Synthetic polymer distribution pipes }\end{array}$ \\
\hline
\end{tabular}

Source: [74]

pollutant metabolites in the 'bound' residue fraction of plant cell walls compared to the vacuole, where enzymatic and metabolic activities may occur [80]. However, toxicity of organic pollutants may be based on plant part viz root and leave. To the leave cell, toxic effects may include cell ultrastructure, biosynthesis, membrane stability and DNA while to the root cell, toxic effects include inordinate mitotic division [81]. Other effects may be on plant physiological and biochemical responses. Some recent studies [82-85], found that the system of defense and growth of Chara vulgaris L., Lemna minor L., H. dubia (B1.) Backer and Potamogeton perfoliatus $L$ respectively are affected by Linear Alkylbenzene Sulphonate, (LAS). Furthermore, our re-intepretation of their data reveals that the effects are varied among the different aquatic plant species. Similarly, [86] reported that at concentration of 840 $\mathrm{mg} / \mathrm{L}$ of ammonium nitrate in water, the growth rate, carbon contents, carbon-nitrogen ratio, photochemical cells and induced reactive oxygen stress (ROS) of Lemna minor L (Duckweed) was reduced, resulting in cell mortality of the aquatic plant. A simple indicator of aquatic plants exposure to organic pollutant is seen by the increased ROS production, leading to plants inability to do its regular ecological function of regulating nutrients in aquatic environment [57]. Information regarding the toxic effects of organic pollutants especially POPs on aquatic plant species or macrophyte is very scarce. Therefore, more studies are required to fill this knowledge gap.

\subsubsection{Aquatic animals}

Available oxygen in water is reduced organic pollutants. This affects water organisms by causing reduced fitness or death from asphyxiation. Effects also include increased turbidity (especially by petroleum-related wastes) of the water, which reduces the available light for photosynthetic organisms and potentially leading to its death. It can also settle on the benthic and alters the characteristics. Organic pollutants have been detected in marine organisms, including the green mussel, Perna viridis [87-90], barnacles [91], odontocete species [92] and fish species [58-61, 93].

\subsubsection{Human health}

Environmental xenobiotic compounds have the potential to induce adverse effects on human health [94]. A common example is hydrophobic 
contaminant like POPs are known to be a potential endocrine disruptor compounds. Although, impact of organic pollutants to human health is yet to be fully examined [95-99], evidences still exists which correlates development and manifestation of some chronic diseases to exposure of certain organic chemicals. Particular, cancer cases has been greatly linked [74]. Other toxic effects could be on ovarian function in women [100], reproductive disorders in both male and female [101], female breast cancer [102], blood poisoning, eyes and skin irritation (by exogenous pollutant e.g. LAS) [103].

\section{Decontamination strategy: Phytoreme- diation}

According to United Nations Environment Programme [104], the efficient use of plants for removing, detoxifing, or immobilising environmental contaminants is regarded as phytoremediation. The strategy is eco-friendly and cheap. The concept of phytoremediation of contaminated medium has been extensively discussed in many scientific, governmental and non-governmental studies [41, 104-115]. The overall objective of any treatment method is to create a final solution that is protective of human health and the environment [29]. Whilst there are many studies on remediation of contaminated soil by plant, aquatic medium by aquatic plants have generally been less studied and reviewed. Aquatic plants are extremely important components of an aquatic ecosystem for primary productivity and nutrient cycling [116-118] and providing refuge, habitat and food for some aquatic organisms. Aquatic phytoremediation involves the use of plants for the removal of contaminants from aqueous solutions. Generally, members of Cyperaceae, Potamogetonaceae, Ranunculaceae, Typhaceae, Haloragaceae, Hydrocharitaceae, Najadaceae, Juncaceae, Pontederiaceae, Zosterophyllaceae, Lemnaceae, mainly represent aquatic plants [4]. These plants are either emergent (i.e their roots are attached to the substrate at the bottom of water bodies while the leaves grow to or above the surface of the water), submerged (their root system is attached to the substrate but their leaves do not reach the surface of the water), or free floating (i.e exclusively found on the surface of water bodies, usually found in standing or slow moving waters) [115]. The overview of phytoremediation techniques or mechanism for the different pollutants is presented in Figure 3. For heavy metals removal mechanism include phytoextraction, phytostabilzation, phytoaccumulation, phytofilteration (rhizofilteration/ blastofiltration) while for organic pollutants mechanism include phytodegradation, phytostimulation, phytotransformation, phytovolatilization, phytodetoxication, phytoassimilation, phytoevaporation. Phytoextraction and phytoaccumulation technique is based on hyper-accumulation, contaminant extraction and capture by plant; phytofilteration is based on the use of plant roots (rhizofiltration) or seedlings (blastofiltration) to accumulate, extract and

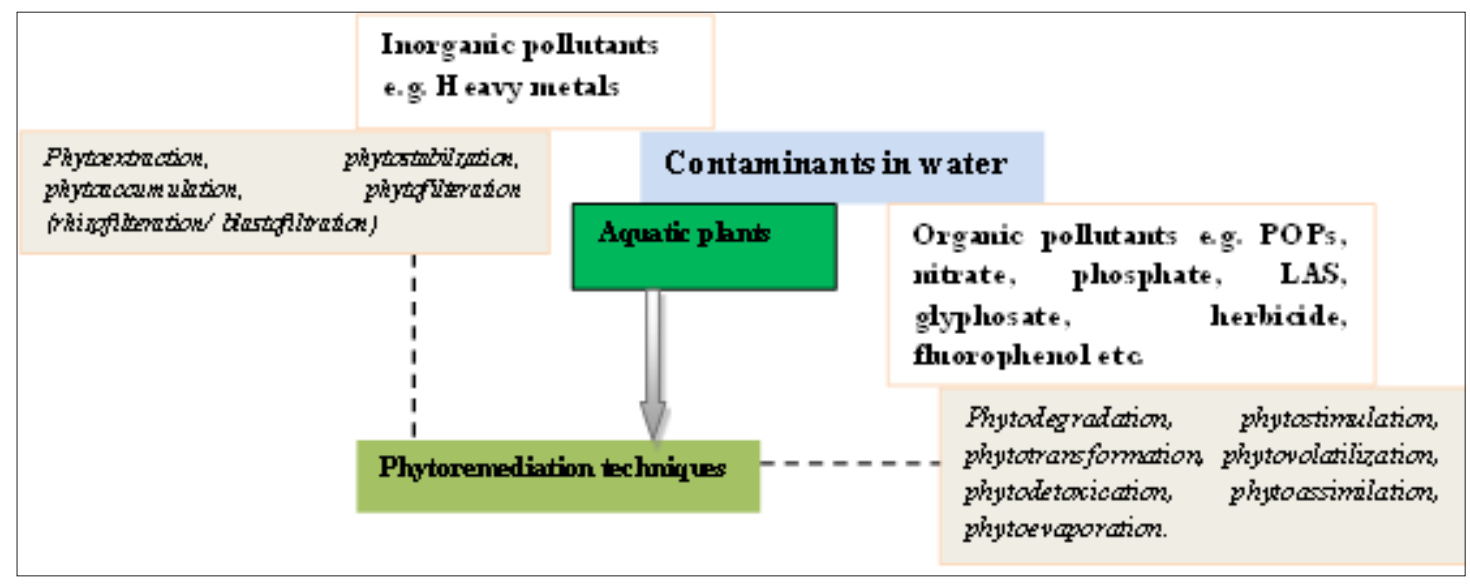

Fig. 3. Overview of phytoremediation techniques by aquatic plant for both organic and inorganic contaminants removal in water 
capture contaminants; phytostabilization is based on complexation and/or contaminant destruction; phytodegradation is based on contaminant destruction; phytovolatilization is based on volatilisation by leaves, contaminants extraction from media and release into air; phytoassimilation is based on contaminant transport and metabolism in plant chloroplast [119-120].

Research status of aforementioned phytoremediation techniques is either at laboratory (involving use of hydroponics), pilot or field applications stages (involving use of constructed wetlands) $[106,107,121]$ (see Figure 4). Phytoextraction and phytoaccumulation is at laboratory, pilot and field applications stages, phytofilteration is at laboratory and pilot scale stages, phytostabilization, phytodegradation (including rhizodegradation) is at field demonstration and application stage, phytovolatilization is at laboratory and field application stages while phytoassimilation, phytoevaporation, phytodetoxication, phytostimulation and phytotransformation is at laboratory or field demonstration stages. In any approach, at the end of the exercise, plant biomass is often harvested, dried and ashed for disposal or extracted using appropriate solvent before analysis. Aquatic plants which operate by rhizofilteration are preferable in aquatic phytoremediation than those plants that efficiently transfer the contaminants (translocators) from root to shoot. The reason is that translocators can potentially pollute above ground biomass, which increases the cost of processing, as well as the risk of exposing the ecosystem to the contaminated plants [4]. The analyses for heavy metals and organic pollutants concentrations in plant biomass are often done by spectroscopic and chromatographic techniques following extraction processes. Extraction technique for heavy metals is commonly by acid digestion while organic pollutants include liquid-liquid extraction (LLE), solid-phase extraction (SPE) and matrix solid-phase dispersion (MSPD). Common techniques for analysis after extraction include atomic absorption spectroscopy (for heavy metals) $[6,24]$, ultraviolet-visible spectroscopy (for dyes), high performance liquid chromatography (HPLC), liquid chromatography/tandem mass spectrometry (LC-MS/MS) or gas chromatography/mass spectrometry (GCMS) (for agricultural chemicals and
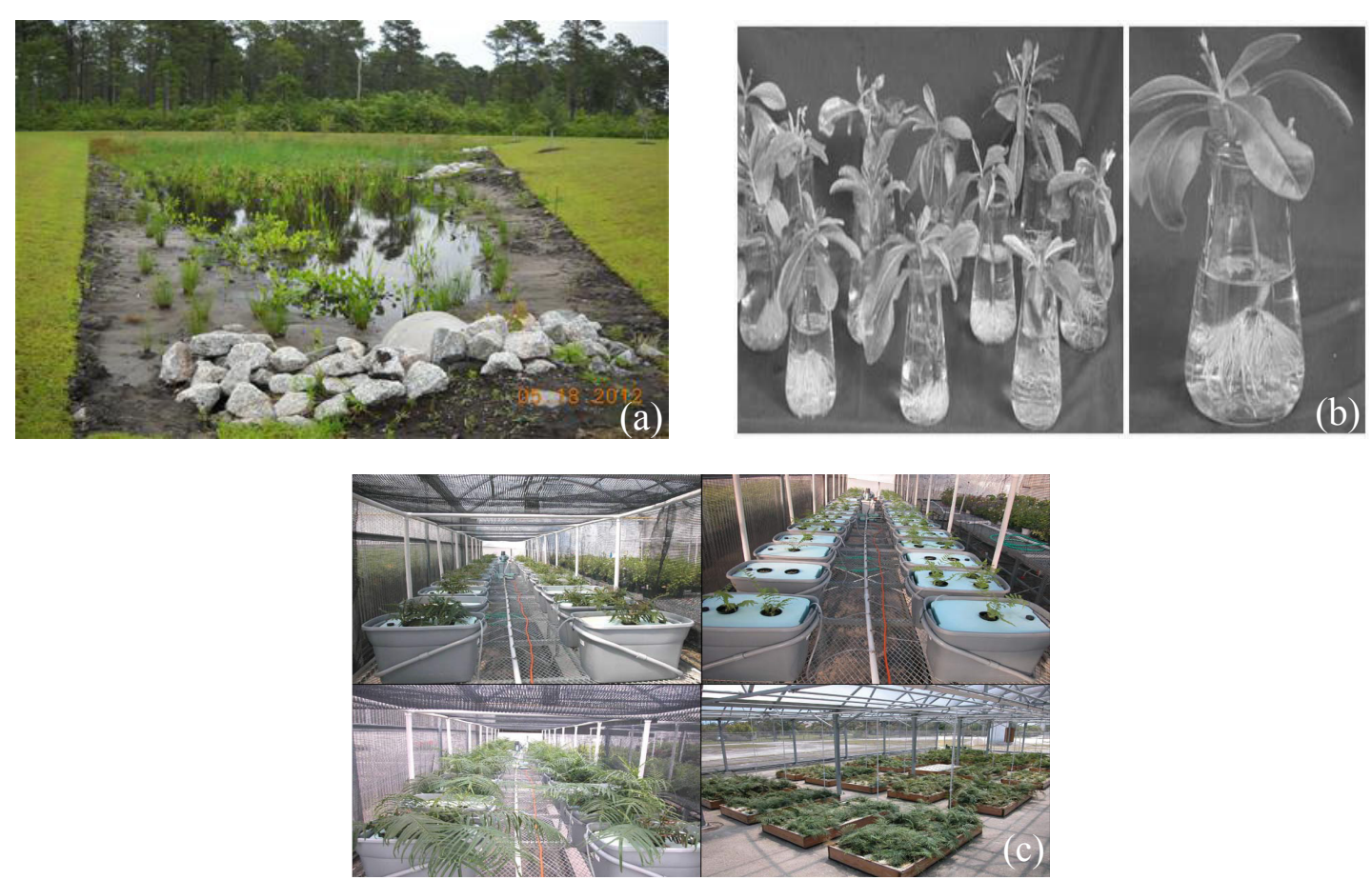

Fig. 4. Experimental system for aquatic phytoremediation. (a) Field experiment showing a constructed wetland [122], (b) Pilot scale setup using Pteris vittata for removal of As from contaminated water [80] (c) Hydroponic system developed for rhizofiltration of environmental contaminants by Talinum cuneifolium (Portulacaceae) [4]. 
petroleum hydrocarbons).

\subsection{Physicochemical factors affecting phytoremediation}

Cellular mechanism for detoxification and tolerance has been discussed recently [112]. In general, the efficiency of removal by aquatic plants depends on water and contaminant physico-chemistry as well as physiology and genotype of the plant $[4,123-$
124]. However, in this study emphasis was placed on the physiochemistry summarized in Table 6 . These parameters can be manipulated or modified in water to enhance phytoremediation.

Currently, studies modifying water physicochemistry for phytoremediation of toxic chemicals is at infancy. There is therefore, need for more efforts for their effective use in the future. For metals,

Table 6. Physical and chemical factors known to affect the pollutants uptake, accumulation, and toxicity

\begin{tabular}{|c|c|}
\hline Parameter & Effects \\
\hline \multicolumn{2}{|l|}{ Heavy metal } \\
\hline Temperature & More uptake/toxicity at higher temperatures \\
\hline Light & Uptake is light dependent in some cases \\
\hline $\mathrm{pH}$ & Lower $\mathrm{pH}$ generally increases the uptake/capacity \\
\hline Salinity Monovalent Cations $(\mathrm{K}, \mathrm{Na})$ & Lower salinity increases the content/toxicity \\
\hline Divalent Cations $\mathrm{Ca}, \mathrm{Mg}, \mathrm{Mn}, \mathrm{Fe}$ & Increasing monovalent cations reduces the uptake \\
\hline Anions & Increasing divalent cations reduces the uptake \\
\hline Organic Acids & Reduces uptake and toxicity \\
\hline Sediment Fraction & Binds metals, reduces uptake/toxicity \\
\hline Heavy Metals & $\begin{array}{l}\text { Reduces uptake/toxicity by binding metals Complex metals, } \\
\text { reduces uptake/toxicity } \mathrm{Zn} / \mathrm{Cd}, \mathrm{Ni}, \mathrm{Cu} \text { combinations are } \\
\text { antagonistic. } \mathrm{Fe} \text { can stimulate } \mathrm{Cu} \text { accumulation }\end{array}$ \\
\hline Suspended solids & Complex metals, reduces uptake/toxicity \\
\hline Sulphate & Insignificant but reduces uptake slightly \\
\hline Nitrate(N) & Significantly reduces toxicity \\
\hline Polypeptides & Reduces uptake/toxicity by complexation \\
\hline Polysachharides & Chelate metals, reduces uptake/toxicity \\
\hline Sulphur (amino acids) & Reduces uptake and toxicity indirectly \\
\hline Extracellular Products & Reduces toxicity \\
\hline \multicolumn{2}{|l|}{ Source: $[125]$} \\
\hline \multicolumn{2}{|l|}{ Organic pollutants } \\
\hline Solubility and concentration of organic pollutants & Increases uptake \\
\hline $\mathrm{pH}$ & Lower $\mathrm{pH}$ generally increases the uptake \\
\hline Light intensity & Uptake is light dependent in some cases \\
\hline Nitrates & Significantly reduces removal \\
\hline co-occurring ions & Increasing dissolved ions reduces the uptake \\
\hline Partition coefficients & $\begin{array}{l}\text { High partition coefficient between octanol and water }\left(\mathrm{K}_{\mathrm{OW}}\right) \text {, and } \\
\text { low partition coefficient between octanol and air }\left(\mathrm{K}_{\mathrm{OA}}\right) \text { increases } \\
\text { uptake/absorption from water and air respectively }\end{array}$ \\
\hline Molecular mass of pollutants & Generally, mass $<1000$ increases uptake \\
\hline Lipid content & High lipid contents increases uptake/toxicity \\
\hline Temperature & $\begin{array}{l}\text { Higher temperature coefficient for diffusion processes of organic } \\
\text { pollutants can accelerate passive absorption by the plant. On the } \\
\text { other hand, temperature rise stimulated transpiration stream rate } \\
\text { and enzyme activity of plants }\end{array}$ \\
\hline Transpiration stream concentration factor (TSCF) & $\begin{array}{l}\text { The TSCF can show the capacity of organic pollutant } \\
\text { translocation from roots to aboveground parts. }\end{array}$ \\
\hline
\end{tabular}

Sources: [80],[81], [113], [126-132]. 
phytoextraction capabilities of many plant species can be enhance by reducing the concentration of organic acids in the water, since organic acids are known to form complexes with metals $[6,13,65$, 125]. Reducing organic acid will thereby increase the concentration of free metal ions readily available for uptake. In addition, the bioavailability of metals can also be enhanced by aquatic plant roots exuding acidifying protons in water. The lowering of water $\mathrm{pH}$ increases the adsorption of heavy metals and reduces their concentrations in the aqueous solution [6, 65, 125, 133-134]. Also, the salt contents in terms of salinity, when in high concentrations reduces uptake of metals in water. For organic pollutant uptake and translocation by plants, parameter such as molecular mass and hydrophobicity with partition coefficients (between octanol and water $\left(\mathrm{K}_{\mathrm{OW}}\right)$ /air $\left(\mathrm{K}_{\mathrm{OA}}\right)$ ) plays crucial roles. Many reports have shown that high $K_{\mathrm{OW}}$ and low $\mathrm{K}_{\mathrm{AO}}$ values of organic pollutants correlated positively to easy (high) uptake of organic pollutants in water and absorption from air by aquatic plants $[80,127$ 130]. Succinctly, when $\log \mathrm{K}_{\text {ow }}$ is less than 1 , the organic pollutant becomes more soluble in water and mainly absorb on the plant roots at a rate surpassing passive influx into the transpiration stream (measured as TSCF) while at $\log$ Kow $>3.5$, due to high sorption on the roots, aquatic plants may not or very slowly passed the contaminants into the transpiration stream and further to the stems and leaves $[80,127]$. $\log \mathrm{K}_{\text {ow }}$ values of some frequently found organic contaminants in the environment have been reviewed [80]. Lipid content has the strongest influence on the uptake of organic pollutants, since most of the organic pollutants are hydrophobic organic contaminants (HOCs). Other factors which impact uptake of by influencing the adsorption of organic pollutants on sediments or chelates formation; include metal type in the solution, dissolved organic carbon (DOC) concentration, $\mathrm{pH}$, organic matter content, light intensity and presence of nitrate. High intensity of light and presence of nitrate was reported to negatively affect perchlorate removal by Pistia $s p$. [131] and willow trees grown in hydroponic solution [135]. These results suggest that for successful phytoremediation of metal/organic polluted water, a strategy should be developed to combine a rapid screening of aquatic plant species possessing hyperacumulating tendency with practices focusing on physicochemical factors listed in Table 6.

\subsection{Phytoremediation of heavy metal polluted water}

Literature reviewed reveals that many aquatic species have been identified and tested for the phytoremediation of selected heavy metals (As, $\mathrm{Cu}$, $\mathrm{Cr}, \mathrm{Hg}, \mathrm{Cd}, \mathrm{Ni}, \mathrm{Pb}$ and $\mathrm{Zn}$ ) from the polluted water (Table 7). These include sharp dock (Polygonum amphibium L.), duck weed (Lemna minor L.), water hyacinth (Eichhornia crassipes), water lettuce ( $P$. stratiotes), water dropwort (Oenathe javanica (BL) DC), calamus (Lepironia articulate), pennywort (Hydrocotyle umbellate L.), Water fern (Azolla filiculoides), Poaceae (Phragmites communis Trin), spiny water nymph, spiny naiad and holly-leaved naiad (Najas marina), Water lilies (Nymphaea spontanea), Poaceae (Phragmites australis Cav.), Se a clubrush, cosmopolitan bulrush, alkali bulrush, saltmarsh bulrush, and bayonet grass (Bolboschoenus maritimus L.), water-starwort (Callitriche cophocarpa Sendtn), umbrella palm (Cyperus alternifolius), Salviniaceae (Salvinia herzogii), Water Mint (Mentha aquatica L.), Water Mint (Mentha sylvestris L.), Canna (Canna $\times$ generalis), Cannaceae (Canna indica L.), giant baby tears (Micranthemum umbrosum), aquatic moss (Warnstorfia fluitans), hippo grass (Vossia cuspidate), blue moon (Iris sibirica), marigold (Tagetes erecta), yellow bur head (Limnocharis flava), willow (Salix matsudana), Alpine pennycress (Noccaea caerulescens), Mint (Elsholtzia argyi) and Mint (Elsholtzi splendens) (Table 7). The summary of concentrations, period, experimental framework, removable rate of different aquatic plants reported in literature for heavy metals phytoremediation is presented in Table 7.

Some plants are considered hyper-accumulator due to their well-developed fibrous root system and large biomass e.g Azolla species, water hyancinth, 
duckweed etc. Removal rates by the water hyancinth in hydroponic solution for $\mathrm{Cd}$, and $\mathrm{Zn}$ was $50-90 \%$ for both metals [142] while for $\mathrm{Ni}$ removal was $68 \%$ in field experiment [150] and $19.84 \%$ in hydroponics after $10 \mathrm{~d}$ exposure to 15 $\mathrm{mg} / \mathrm{L}$ of Ni [177]. Furthermore, strong removal was also observed for Cd removal (>90\%) conducted in a pot [25]. Also using water hyancinth, Lu et. al., [142] demonstrated the potential for the removal of $\mathrm{Cd}$ and $\mathrm{Zn}$. In their study, the plant was exposed to concentrations of $0.5,1,2$ and $4 \mathrm{mg} / \mathrm{L}$ of $\mathrm{Cd}$ and 5 , 10,20 , and $40 \mathrm{mg} / \mathrm{L}$ of $\mathrm{Zn}$, and harvested separately after days $0,4,8$ and 12 . They observed fast removal in the first 4 days with overall removal rates of 50$90 \%$. They concluded that the plant was a moderate accumulator of $\mathrm{Cd}$ and $\mathrm{Zn}$ at low concentrations. Abbas et al [173] assessed the effectiveness of water hyacinth for the phytoremediation of landfill leachate for the period of 15 days. The authors used fifteen plastic containers in experimental setup and the plant was fitted as a floating bed with the help of thermopole sheet. Results from their study showed that the removal rates of heavy metals like $\mathrm{Zn}, \mathrm{Pb}, \mathrm{Cu}$ and $\mathrm{Ni}$ from landfill leachate gradually increased from day 3 to day 15 of the experiment. The maximum removal rate for heavy metals such as for $\mathrm{Zn}(80-90 \%), \mathrm{Pb}(76-84 \%), \mathrm{Cu}(72-87 \%)$ and $\mathrm{Ni}(68-81 \%)$ was attained by the plants. Low values $(<1)$ of $\mathrm{BCF}$ and translocation factor, indicating low transport of heavy metals from roots to the above-ground parts of the plants. Therefore, from their results, they suggested that the plant is suitable for the removal of pollution load from landfill leachate. Priyanka et al [162] tested water

Table 7. Summary of selected heavy metals in aqueous medium associated with aquatic plants remediation

\begin{tabular}{|c|c|c|c|c|c|c|}
\hline Metal & Concentration & $\begin{array}{l}\text { Exposure } \\
\text { duration }\end{array}$ & $\begin{array}{c}\text { Experimental } \\
\text { framework }\end{array}$ & Plant specie & $\begin{array}{l}\text { Removal } \\
\text { rate }(\%)\end{array}$ & References \\
\hline \multirow[t]{5}{*}{ As } & 0.5 & $21 \mathrm{~d}$ & Field & Duckweed (L. minor) & 5 & {$[136]$} \\
\hline & $96 \mu \mathrm{g} / \mathrm{L}$ & $3 \mathrm{~d}$ & Field & Duckweed (L. minor) & 7070 & [137] \\
\hline & $0-100 \mu \mathrm{M}$ & $192 \mathrm{~h}$ & Hydroponic & Warnstorfia fluitans & 82 & [138] \\
\hline & $16.31 \mathrm{ppb}$ & $25 \mathrm{~d}$ & & Duckweed (L. minor) & 90.95 & [139] \\
\hline & 20 & $24 \mathrm{~h}$ & Field & Water lettuce (Pistia stratiotes) & 77 & {$[41]$} \\
\hline \multirow[t]{16}{*}{ Cd } & $1-8$ & $12 \mathrm{~d}$ & Hydroponics & Duckweed (Wolffia globosa) & $50-90$ & [140] \\
\hline & $17.20-26.25 \mu \mathrm{g} / \mathrm{L}$ & Inconsistent & Field & Poaceae (Phragmites communis & $45.6-80$ & [141] \\
\hline & $17.20-26.25 \mu \mathrm{g} / \mathrm{L}$ & Inconsistent & Field & $\begin{array}{l}\text { Trin) } \\
\text { spiny water nymph, spiny naiad and } \\
\text { holly-leaved naiad (Najas marina) }\end{array}$ & $45.6-80$ & [141] \\
\hline & $0.5-4$ & $12 \mathrm{~d}$ & Hydroponic & $\begin{array}{l}\text { Water hyacinth (Eichhornia } \\
\text { crassipes) }\end{array}$ & $50-90$ & [142] \\
\hline & $0.003-10^{-7} \mathrm{M}$ & 28 & Field & Duckweed (L. minor) & 95 & [143] \\
\hline & $0.5-3.0$ & 22 & Field & Duckweed (L. minor) & $42-78$ & [144] \\
\hline & & & Hydroponic & Veronica anagallis & $50-90$ & [145] \\
\hline & & & Hydroponic & Epilobium laxum & $50-90$ & [145] \\
\hline & 0.018 & $7 \mathrm{~d}$ & Field & Duckweed (L. minor) & 78 & {$[146]$} \\
\hline & $0.01-10$ & $48 \mathrm{~h}$ & Field & Duckweed (L. minor) & 97.32 & {$[147]$} \\
\hline & $0-12.39$ & $28 \mathrm{~d}$ & Field & Duckweed (L. minor) & $72-91$ & [148] \\
\hline & $10 \mu \mathrm{M}$ & $7 \mathrm{~d}$ & Field & Duckweed (L. minor) & 38 & [149] \\
\hline & $0-12.39$ & 28 & Field & Water fern (Azolla filiculoides) & $72-91$ & [148] \\
\hline & $1.47 \mathrm{ppb}$ & $25 \mathrm{~d}$ & Hydroponic & Duckweed (L. minor) & 97.79 & {$[139]$} \\
\hline & $\begin{array}{c}\text { Variable } \\
\text { concentrations }\end{array}$ & $10 \mathrm{~d}$ & Field & $\begin{array}{l}\text { umbrella palm (Cyperus } \\
\text { alternifolius) }\end{array}$ & 3 & {$[150]$} \\
\hline & $\begin{array}{c}\text { Variable } \\
\text { concentrations }\end{array}$ & $10 \mathrm{~d}$ & Field & $\begin{array}{l}\text { Water hyacinth (Eichhornia } \\
\text { crassipes) }\end{array}$ & 20 & {$[150]$} \\
\hline
\end{tabular}


Table 7. (Continute)

\begin{tabular}{|c|c|c|c|c|c|c|}
\hline Metal & Concentration & $\begin{array}{l}\text { Exposure } \\
\text { duration }\end{array}$ & $\begin{array}{c}\text { Experimental } \\
\text { framework }\end{array}$ & Plant specie & $\begin{array}{l}\text { Removal } \\
\text { rate }(\%)\end{array}$ & References \\
\hline \multirow[t]{27}{*}{$\mathrm{Cr}$} & $1-8$ & $12 \mathrm{~d}$ & Hydroponics & Duckweed (Wolffia globosa) & $50-90$ & {$[140]$} \\
\hline & $<0-2.20 \mu \mathrm{g} / \mathrm{L}$ & Inconsistent & Field & Poaceae (Phragmites communis & $45.6-80$ & {$[141]$} \\
\hline & & & & Trin) & & \\
\hline & $<0-2.20 \mu \mathrm{g} / \mathrm{L}$ & Inconsistent & Field & spiny water nymph, spiny naiad and & $45.6-80$ & {$[141]$} \\
\hline & & & & holly-leaved naiad (Najas marina) & & \\
\hline & $1.0-2.0$ & $24 \mathrm{~h}$ & Field & Salviniaceae (Salvinia herzogii) & $70-83$ & {$[151]$} \\
\hline & $0.1-1.0$ & $12 \mathrm{~d}$ & Hydroponic & Water fern (Azolla caroliniana) & 100 & {$[152]^{\mathrm{a}}$} \\
\hline & $0.1-1.0$ & $12 \mathrm{~d}$ & Hydroponic & Water fern (Azolla caroliniana) & 74 & {$[152]^{\mathrm{b}}$} \\
\hline & 1 & $15 \mathrm{~d}$ & & Duckweed (L. minor) & 96.94 & {$[153]$} \\
\hline & $1.0-2.0$ & $24 \mathrm{~h}$ & Hydroponic & Water lettuce (Pistia stratiotes) & $58-80$ & {$[151]$} \\
\hline & $1-10$ & $9 \mathrm{w}$ & Hydroponic & Water lilies (Nymphaea spontanea) & 31.6 & {$[154]$} \\
\hline & $<0-0.51$ & Inconsistent & Field & Poaceae (Phragmites australis & $50-80$ & {$[155]$} \\
\hline & & & & Cav.) & & \\
\hline & $<0-0.51$ & Inconsistent & Field & $\begin{array}{l}\text { Sea clubrush, cosmopolitan bulrush, } \\
\text { alkali bulrush, saltmarsh bulrush, } \\
\text { and bayonet grass (Bolboschoenus } \\
\text { maritimus L.) }\end{array}$ & $50-80$ & {$[155]$} \\
\hline & $0.04-98$ & $60 \mathrm{~d}$ & & Duckweed (L. minor) & $25-77.42$ & {$[156]$} \\
\hline & 10 & $3 \mathrm{w}$ & Hydroponic & water-starwort (Callitriche & $50-80$ & {$[157]^{\mathrm{a}}$} \\
\hline & & & & cophocarpa Sendtn) & & \\
\hline & $0.25-5.0$ & $14 \mathrm{~d}$ & $\begin{array}{c}\text { Pilot with } \\
\text { continuous flow }\end{array}$ & Duckweed (L. minor) & $76.4-20.0$ & {$[134]^{\mathrm{a}}$} \\
\hline & 10.946 & $7 \mathrm{~d}$ & & Duckweed (L. minor) & 99.97 & {$[158]$} \\
\hline & 10.4 & $7 \mathrm{~d}$ & Hydroponic & Duckweed (L. minor) & 75 & [159] \\
\hline & 0.776 & $7 \mathrm{~d}$ & Field & Duckweed (L. minor) & 63 & {$[146]$} \\
\hline & $0-0.20 \mathrm{mM}$ & $16 \mathrm{~d}$ & & Duckweed (L. minor) & 27.6 & {$[160]$} \\
\hline & & & & Phalari arundinacea & & {$[161]$} \\
\hline & 2 & $15 \mathrm{~d}$ & Field & $\begin{array}{l}\text { Water hyacinth (Eichhornia } \\
\text { crassipes) }\end{array}$ & 99.9 & {$[162]^{\mathrm{a}}$} \\
\hline & $67.33 \mathrm{ppb}$ & $25 \mathrm{~d}$ & & Duckweed (L. minor) & 90.25 & [139] \\
\hline & $0-12.39$ & $28 \mathrm{~d}$ & Field & Duckweed (L. minor) & $72-91$ & [148] \\
\hline & $0-12.39$ & $28 \mathrm{~d}$ & Field & Water fern (Azolla filiculoides) & 90 & {$[148]$} \\
\hline \multirow[t]{9}{*}{$\mathrm{Cu}$} & $1.95-4.20 \mu \mathrm{g} / \mathrm{L}$ & Inconsistent & Field & Poaceae (Phragmites communis & $45.6-80$ & {$[141]$} \\
\hline & $1.95-4.20 \mu \mathrm{g} / \mathrm{L}$ & Inconsistent & Field & $\begin{array}{l}\text { Trin) } \\
\text { spiny water nymph, spiny naiad and } \\
\text { holly-leaved naiad (Najas marina) }\end{array}$ & $45.6-80$ & [141] \\
\hline & $1-7$ & $4 \mathrm{~d}$ & Hydroponic & Duckweed (L. minor) & 77.78 & [163] \\
\hline & 1 & $15 \mathrm{~d}$ & Hydroponic & Duckweed (L. minor) & 96.94 & {$[153]$} \\
\hline & $1-7$ & $15 \mathrm{~d}$ & Hydroponic & Mint (Elsholtzia argyi) & $50-90$ & [164] \\
\hline & $1-7$ & $15 \mathrm{~d}$ & Hydroponic & Mint (Elsholtzi splendens) & $45-80$ & [164] \\
\hline & $1.23-1.75$ & Inconsistent & Field & Poaceae (Phragmites australis & $50-80$ & {$[155]$} \\
\hline & & & & Cav.) & & \\
\hline & $1.23-1.75$ & Inconsistent & Field & $\begin{array}{l}\text { Sea clubrush, cosmopolitan bulrush, } \\
\text { alkali bulrush, saltmarsh bulrush, } \\
\text { and bayonet grass (Bolboschoenus } \\
\text { maritimus L.) }\end{array}$ & $50-80$ & {$[155]$} \\
\hline
\end{tabular}


Table 7. (Continute)

\begin{tabular}{|c|c|c|c|c|c|c|}
\hline Metal & Concentration & $\begin{array}{l}\text { Exposure } \\
\text { duration }\end{array}$ & $\begin{array}{c}\text { Experimental } \\
\text { framework }\end{array}$ & Plant specie & $\begin{array}{l}\text { Removal } \\
\text { rate }(\%)\end{array}$ & References \\
\hline & $0.003-10^{-7} \mathrm{M}$ & $7 \mathrm{~d}$ & & Duckweed (L. minor) & 86.5 & [143] \\
\hline & 0.46 & $20 \mathrm{~d}$ & & Duckweed (L. minor) & 71.4 & [165] \\
\hline & 4.359 & $7 \mathrm{~d}$ & & Duckweed (L. minor) & 99.97 & [158] \\
\hline & 3 & $7 \mathrm{~d}$ & Hydroponic & Duckweed (L. minor) & 40 & [159] \\
\hline & 1.432 & $7 \mathrm{~d}$ & Field & Duckweed (L. minor) & 86 & [146] \\
\hline & $67 \mu \mathrm{g} / \mathrm{L}$ & $3 \mathrm{~d}$ & & Duckweed (L. minor) & 87 & {$[137]$} \\
\hline & 0.5 and 0.25 & $7 \mathrm{~d}$ & & Duckweed (L. minor) & 0 & [166] \\
\hline & $1-5$ & $4 \mathrm{w}$ & & Duckweed (L. minor) & 90 & {$[167]$} \\
\hline & $200 \mu \mathrm{M}$ & $3 \mathrm{~d}$ & & Duckweed (L. minor) & 20.2 & [168] \\
\hline & & & & Vossia cuspidata & & {$[169][170]$} \\
\hline & 2 & $2 \mathrm{w}$ & & Duckweed (L. minor) & 54.2 & [171] \\
\hline & $0.05-1.2$ & $5 \mathrm{~d}$ & & Duckweed (L. minor) & 83.3 & [172] \\
\hline & $0-12.39$ & $28 \mathrm{~d}$ & Field & Duckweed (L. minor) & $72-91$ & [148] \\
\hline & $23.84 \mathrm{ppb}$ & $25 \mathrm{~d}$ & & Duckweed (L. minor) & 98.46 & [139] \\
\hline & $0-12.39$ & $28 \mathrm{~d}$ & Field & Water fern (Azolla filiculoides) & 80 & [148] \\
\hline & $0.09-0.73$ & $15 \mathrm{~d}$ & Field & $\begin{array}{l}\text { Water hyacinth (Eichhornia } \\
\text { crassipes) }\end{array}$ & $\begin{array}{l}36.98- \\
87.09\end{array}$ & [173] \\
\hline & $0.08-0.46$ & $15 \mathrm{~d}$ & Field & Water lettuce (Pistia stratiotes) & $\begin{array}{c}39.72- \\
72.58\end{array}$ & [173] \\
\hline \multirow[t]{9}{*}{ Hg } & $0.1-1.0$ & $12 \mathrm{~d}$ & Hydroponic & Water fern (Azolla caroliniana) & $75-93$ & [152] \\
\hline & $0.04-98$ & $60 \mathrm{~d}$ & Field & Duckweed (L. minor) & $25-77.42$ & {$[156]$} \\
\hline & 0.23 & $20 \mathrm{~d}$ & Hydroponic & Duckweed (L. minor) & 66.5 & {$[165]$} \\
\hline & 0.5 and 0.25 & $7 d$ & Hydroponic & Duckweed (L. minor) & 0 & [166] \\
\hline & & & Hydroponic & Salix matsudana & & {$[160]$} \\
\hline & $200 \mu \mathrm{M}$ & $3 \mathrm{~d}$ & Hydroponic & Duckweed (L. minor) & 20.2 & {$[168]$} \\
\hline & $0-30 \mu \mathrm{M}$ & $6 \mathrm{~d}$ & Hydroponic & Duckweed (L. minor) & 58.3 & {$[81]$} \\
\hline & & & Field & Limnocharis flava & & [174] \\
\hline & $0.36 \mathrm{ppb}$ & $25 \mathrm{~d}$ & Hydroponic & Duckweed (L. minor) & 82.84 & [139] \\
\hline \multirow[t]{10}{*}{$\mathbf{N i}$} & $1-8$ & $14 \mathrm{~d}$ & Hydroponic & Water Mint (Mentha aquatica L.) & 22.3 & [175] \\
\hline & $1-8$ & $14 \mathrm{~d}$ & Hydroponic & Water Mint (Mentha sylvestris L.) & 17.9 & {$[175]$} \\
\hline & $0.0-10.0$ & $24 \mathrm{~h}$ & Batch & Duckweed (L. minor) & 82 & {$[176]$} \\
\hline & $1.90-17.30 \mu \mathrm{g} / \mathrm{L}$ & Inconsistent & Field & $\begin{array}{l}\text { Poaceae (Phragmites communis } \\
\text { Trin) }\end{array}$ & $45.6-80$ & {$[141]$} \\
\hline & $1.90-17.30 \mu \mathrm{g} / \mathrm{L}$ & Inconsistent & Field & $\begin{array}{l}\text { spiny water nymph, spiny naiad and } \\
\text { holly-leaved naiad (Najas marina) }\end{array}$ & $45.6-80$ & [141] \\
\hline & $1.98-4.51$ & Inconsistent & Field & $\begin{array}{l}\text { Poaceae (Phragmites australis } \\
\text { Cav.) }\end{array}$ & $50-80$ & {$[155]$} \\
\hline & $1.98-4.51$ & Inconsistent & Field & $\begin{array}{l}\text { Sea clubrush, cosmopolitan bulrush, } \\
\text { alkali bulrush, saltmarsh bulrush, } \\
\text { and bayonet grass (Bolboschoenus } \\
\text { maritimus L.) }\end{array}$ & $50-80$ & {$[155]$} \\
\hline & $0.04-98$ & $60 \mathrm{~d}$ & Field & Duckweed (L. minor) & $25-77.42$ & {$[156]$} \\
\hline & 15 & $10 \mathrm{~d}$ & Hydroponic & $\begin{array}{l}\text { Water hyacinth (Eichhornia } \\
\text { crassipes) }\end{array}$ & 19.54 & {$[177]$} \\
\hline & & & Hydroponic & Tagetes erecta & & {$[178]$} \\
\hline
\end{tabular}


Table 7. (Continute)

\begin{tabular}{|c|c|c|c|c|c|c|}
\hline Metal & Concentration & $\begin{array}{l}\text { Exposure } \\
\text { duration }\end{array}$ & $\begin{array}{c}\text { Experimental } \\
\text { framework }\end{array}$ & Plant specie & $\begin{array}{l}\text { Removal } \\
\text { rate }(\%)\end{array}$ & References \\
\hline & $0-12.39$ & 28 & Field & Duckweed (L. minor) & $72-91$ & [148] \\
\hline & $0-12.39$ & 28 & Field & Water fern (Azolla filiculoides) & $72-91$ & {$[148]$} \\
\hline & $346.81 \mathrm{ppb}$ & $25 \mathrm{~d}$ & & Duckweed (L. minor) & 98.08 & [139] \\
\hline & Variable & $10 \mathrm{~d}$ & Field & Umbrella palm (Cyperus & 66 & {$[150]$} \\
\hline & concentrations & & & alternifolius), & & \\
\hline & Variable & $10 \mathrm{~d}$ & Field & Canna (Canna $\times$ generalis) & 31 & {$[150]$} \\
\hline & concentrations & & & & & \\
\hline & $0.07-1.83$ & $15 \mathrm{~d}$ & Field & Water hyacinth (Eichhornia & $25.68-$ & [173] \\
\hline & & & & crassipes) & 81.56 & \\
\hline & $0.03-1.36$ & $15 \mathrm{~d}$ & Field & Water lettuce (Pistia stratiotes) & $28.96-$ & {$[173]$} \\
\hline & $\begin{array}{c}\text { Variable } \\
\text { concentrations }\end{array}$ & $10 \mathrm{~d}$ & Field & $\begin{array}{l}\text { Water hyacinth (Eichhornia } \\
\text { crassipes) }\end{array}$ & $\begin{array}{c}68.79 \\
68\end{array}$ & {$[150]$} \\
\hline \multirow[t]{17}{*}{$\mathbf{P b}$} & $0.0-10.0$ & $24 \mathrm{~h}$ & Batch & Duckweed (L. minor) & 76 & {$[176]$} \\
\hline & 1 & $15 \mathrm{~d}$ & & Duckweed (L. minor) & 98.55 & [153] \\
\hline & $0.70-4.45 \mu \mathrm{g} / \mathrm{L}$ & Inconsistent & Field & Poaceae (Phragmites communis & $45.6-80$ & {$[141]$} \\
\hline & $0.70-4.45 \mu \mathrm{g} / \mathrm{L}$ & Inconsistent & Field & $\begin{array}{l}\text { Trin) } \\
\text { spiny water nymph, spiny naiad and } \\
\text { holly-leaved naiad (Najas marina) }\end{array}$ & $45.6-80$ & [141] \\
\hline & $0.1-10.0$ & $24 \mathrm{~h}$ & Hydroponic & Duckweed (L. minor) & $58-79$ & [133] \\
\hline & $0.04-98$ & $60 \mathrm{~d}$ & Field & Duckweed (L. minor) & $25-77.42$ & {$[156]$} \\
\hline & $0.003-10^{-7} \mathrm{M}$ & $7 \mathrm{~d}$ & Hydroponic & Duckweed (L. minor) & 93 & [143] \\
\hline & 0.875 & $7 \mathrm{~d}$ & Hydroponic & Duckweed (L. minor) & 99.97 & {$[158]$} \\
\hline & 0.2 & $7 \mathrm{~d}$ & Hydroponic & Duckweed (L. minor) & 85 & [159] \\
\hline & 0.655 & $7 \mathrm{~d}$ & Field & Duckweed (L. minor) & 84 & {$[146]$} \\
\hline & $7.5 \mu \mathrm{g} / \mathrm{L}$ & $3 \mathrm{~d}$ & Field & Duckweed (L. minor) & 1259 & {$[137]$} \\
\hline & $10-41$ & $21 d$ & Field/peat & Cannaceae (Canna indica L.) & 81.16 & [179] \\
\hline & 0.5 and 0.25 & $7 \mathrm{~d}$ & Hydroponic & Duckweed (L. minor) & 0 & {$[166]$} \\
\hline & $200 \mu \mathrm{M}$ & $3 d$ & Hydroponic & Duckweed (L. minor) & 20.2 & [168] \\
\hline & $23.37 \mathrm{ppb}$ & $25 \mathrm{~d}$ & Hydroponic & Duckweed (L. minor) & 99.61 & [139] \\
\hline & $0.09-0.86$ & $15 \mathrm{~d}$ & Field & $\begin{array}{l}\text { Water hyacinth (Eichhornia } \\
\text { crassipes) }\end{array}$ & $\begin{array}{l}36.09- \\
84.41\end{array}$ & [173] \\
\hline & ND-0.55 & $15 \mathrm{~d}$ & Field & Water lettuce (Pistia stratiotes) & $\begin{array}{c}43.02- \\
76.66\end{array}$ & [173] \\
\hline \multirow[t]{6}{*}{ Zn } & $5-40$ & $12 \mathrm{~d}$ & Hydroponic & $\begin{array}{l}\text { Water hyacinth (Eichhornia } \\
\text { crassipes) }\end{array}$ & $50-90$ & [142] \\
\hline & 1 & $15 \mathrm{~d}$ & Field & Duckweed (L. minor) & 95.20 & [153] \\
\hline & $<0 \mu \mathrm{g} / \mathrm{L}$ & Inconsistent & Field & $\begin{array}{l}\text { Poaceae (Phragmites communis } \\
\text { Trin) }\end{array}$ & $45.6-80$ & {$[141]$} \\
\hline & $<0 \mu \mathrm{g} / \mathrm{L}$ & Inconsistent & Field & $\begin{array}{l}\text { spiny water nymph, spiny naiad and } \\
\text { holly-leaved naiad (Najas marina) }\end{array}$ & $45.6-80$ & [141] \\
\hline & $<0-63.5$ & Inconsistent & Field & $\begin{array}{l}\text { Poaceae (Phragmites australis } \\
\text { Cav.) }\end{array}$ & $50-80$ & {$[155]$} \\
\hline & & Inconsistent & Field & $\begin{array}{l}\text { Sea clubrush, cosmopolitan bulrush, } \\
\text { alkali bulrush, saltmarsh bulrush, } \\
\text { and bayonet grass (Bolboschoenus } \\
\text { maritimus L.) }\end{array}$ & $50-80$ & [155] \\
\hline
\end{tabular}


Table 7. (Continute)

\begin{tabular}{|c|c|c|c|c|c|c|}
\hline Metal & Concentration & $\begin{array}{l}\text { Exposure } \\
\text { duration }\end{array}$ & $\begin{array}{c}\text { Experimental } \\
\text { framework }\end{array}$ & Plant specie & $\begin{array}{l}\text { Removal } \\
\text { rate }(\%)\end{array}$ & References \\
\hline & $0.04-98$ & $60 \mathrm{~d}$ & Field & Duckweed (L. minor) & $25-77.42$ & {$[156]$} \\
\hline & $0.003-10^{-7} \mathrm{M}$ & $7 \mathrm{~d}$ & Hydroponic & Duckweed (L. minor) & 63.5 & [143] \\
\hline & $0.2-30$ & $7 \mathrm{~d}$ & Hydroponic & Duckweed (L. minor) & 75 & {$[180]$} \\
\hline & 0.816 & $7 \mathrm{~d}$ & Field & Duckweed (L. minor) & 62 & [146] \\
\hline & $1-5$ & $4 w$ & Field & Duckweed (L. minor) & 90 & {$[167]$} \\
\hline & $730 \mu \mathrm{g} / \mathrm{L}$ & $3 \mathrm{~d}$ & Field & Duckweed (L. minor) & 628 & {$[137]$} \\
\hline & 0.5 and 0.25 & $7 \mathrm{~d}$ & Hydroponic & Duckweed (L. minor) & 0 & [166] \\
\hline \multirow{2}{*}{\multicolumn{2}{|c|}{$200 \mu \mathrm{M}$}} & $3 \mathrm{~d}$ & Hydroponic & Duckweed (L. minor) & 20.2 & [168] \\
\hline & & & Field & Cyperus alternifolius & & [181] [182] \\
\hline & $0-12.39$ & $28 \mathrm{~d}$ & Field & Duckweed (L. minor) & $72-91$ & [148] \\
\hline & $0-12.39$ & $28 \mathrm{~d}$ & Field & Water fern (Azolla filiculoides) & & [148] \\
\hline & & & Hydroponic & $\begin{array}{l}\text { Alpine penny-cress (Noccaea } \\
\text { caerulescens) }\end{array}$ & & [183] \\
\hline & $49.59 \mathrm{ppb}$ & $25 \mathrm{~d}$ & Hydroponic & Duckweed (L. minor) & 98.00 & [139] \\
\hline & $0.91-1.67$ & $15 \mathrm{~d}$ & Field & $\begin{array}{l}\text { Water hyacinth (Eichhornia } \\
\text { crassipes) }\end{array}$ & $\begin{array}{l}21.55- \\
90.18\end{array}$ & [173] \\
\hline & $0.26-1.31$ & $15 \mathrm{~d}$ & Field & Water lettuce (Pistia stratiotes) & $\begin{array}{c}26.99- \\
79.57\end{array}$ & [173] \\
\hline
\end{tabular}

${ }^{a}$ used $\mathrm{Cr}^{6+},{ }^{\mathrm{b}}$ used $\mathrm{Cr}^{3+}$; Concentrations are in $(\mathrm{mg} / \mathrm{L})$ unless otherwise noted; d-days, h-hour(s), w-week(s); field: water samples treated or plant used was collected from aquatic environment, outdoor experiment or involves a constructed wetland, Hydroponics: growing plants in water cultures, or nutrient solution, without soil as a rooting medium; Pilot with continuous flow: wastewater in a continuous flow pond system used to simulate a wastewater treatment pond and a natural wetland as habitat for the plants

hyacinth in clean wastewater at Sukinda chromite mines (SCM) area of Orissa (India) containing high levels of toxic hexavalent chromium (CrVI). Results showed that the plant could remove 99.5\% Cr (VI) of the processed water of SCM in 15 days. Using hydroponics, they [48] tested different levels of $\mathrm{Cd}$ ( 5 to $20 \mathrm{mg} \mathrm{L}^{-1}$ ) rate by three hydrophytes: Gladiolous, Isoetes taiwaneneses Dwvol and Echinodorus amazonicus and observed highest accumulation in Gladiolous than the other two plants. Also, high removal rates following phytofiltration were reported for Elsholtzia argyi (50-90\%) and Elsholtzi splendens (45-80\%) for $\mathrm{Cu}$ [164]. Boonyapookana et al [140] observed high phytoaccumulation rates (reaching $90 \%$ ) for $\mathrm{Cd}$ and $\mathrm{Cr}$ by $W$. globosa, which correlates positively with exposure time and metal concentration were increased. Small water fern (Azolla caroliniana Willd.), was investigated for water purification potential by [152]. The experiment was conducted in 12 days using hydroponic solution polluted by $\mathrm{Hg}$ and $\mathrm{Cr}$. Initial concentrations were $0.1,0.5$ and $1.0 \mathrm{mg} / \mathrm{L}$ for both metals and day 12 , metal contents the solution decreased to $0-0.25 \mathrm{mg} \mathrm{L}^{-1}$, corresponding between $74-100 \%$ removal rates. Baldantoni et al [141] studied the leaves and roots Phragmites communis Trin. (an emergent plant), and Najas marina L. (submerged plant), taken from Lake Averno (Naples, Italy) for levels $\mathrm{Cd}, \mathrm{Cr}$, $\mathrm{Cu}, \mathrm{Fe}, \mathrm{Ni}, \mathrm{Pb}, \mathrm{Zn}$ and found higher accumulation in root than leaves. However, between the two plants, Phragmites communis showied high capability to accumulate trace metals in the roots better than Najas marina [141]. By constructing a wetland in the Venice lagoon watershed, they [155] investigated the removal efficiency of Phragmites australis and Bolboschoenus maritimus in removing $\mathrm{Cr}, \mathrm{Ni}, \mathrm{Cu}$ and $\mathrm{Zn}$ from water. Investigations were conducted over a vegetative season with various distances to the inlet point to assess effects on 
vegetation. Results showed that overall heavy metal concentrations removed ranged from 50-80 $\%$ and $P$. australis was a better phytoaccumulator to in B. maritimus (accumulating more in roots). Using outdoor experiments, capacity examination of Salvinia herzogii (Salviniaceae) and Pistia stratiotes (water lettuce) to remove Cr (III) from water was conducted by [151]. Results from their study showed that both plants efficiently removed Cr (up $83 \%$ for Salviniaceae and up $80 \%$ for water lettuce, Table 7) from water. Furthermore, water lettuce was also found by [173] to be very effective with maximum removal rate over 15 days for $\mathrm{Zn}(80-90 \%), \mathrm{Pb}(76-84 \%), \mathrm{Cu}(72-87 \%)$ and $\mathrm{Ni}(68-81 \%)$ respectively from landfill leachates. The author reported that the plant exhibited low $(<$ 1) bioconcentration factor (BCF) and translocation factor (TF), indicating low transport of heavy metals from roots to the upper parts of the plant. Another excellent $\mathrm{Cr}$ removal from polluted water was found in Callitriche cophocarpa (waterstarwort) by [157]. The authors used a hydroponic culture for up to 3 weeks and reported removal rate up $80 \%$ (Table 7). Nevena et. al., [179] tested an ornamental plant $C$. indica for phytoremediation of $\mathrm{Pb}$ in wastewater. Removal rates of $81.16 \%$ was obtained and therefore concluded that $C$. indica can be used in rhizofiltration systems or floating islands for treatment of water polluted with lead [179]. Most recent studies have used duckweed more when compared to other plants. Axtell et al [176] examined the ability of Lemna minor using a batch process to remove $\mathrm{Pb}$ and $\mathrm{Ni}$ under different laboratory conditions. Initial concentrations were $0.0,5.0$, and $10.0 \mathrm{mg} / 1$ for $\mathrm{Pb}$, and $0.0,2.5$, and $5.0 \mathrm{mg} / \mathrm{l}$ for Ni. Overall, L. minor removed $76 \%$ of $\mathrm{Pb}$ and $82 \%$ of $\mathrm{Ni}$. They further observed that there was no synergistic/antagonistic effect for the multiple metal experiments, in terms of metal removal [176]. In a continuous flow pond system, Uysal [134] examined the ability of Lemna minor to remove $\mathrm{Cr}$ (VI) ions from wastewater. The authors used the system to simulate a wastewater treatment pond and a natural wetland as habitat for the plants and reported removal rates between 20
$-76.4 \%$ suggesting the potentiality of the plants for $\mathrm{Cr}$ removal in wastewater. More recently, [150] studied the uptake of $\mathrm{Cd}, \mathrm{Cr}, \mathrm{Pb}$, and $\mathrm{Zn}$ by four aquatic plants including umbrella palm (Cyperus alternifolius), duckweed (Lemna minor), water hyacinth (Eichhornia crassipes), and canna (Canna $\times$ generalis) in different environments i.e., Gohar Rood river, Zarjoob river, Eynak lagoon, Anzali lagoon, and control solution. Results showed that the highest uptake rates were observed for duckweed fronds $(>70 \%$ ) while highest removal throughout the study for specific plants was water hyacinth $68 \%$, umbrella $66 \%$ and canna $31 \%$ respectively. Based on the results of their study, duckweed was suitable for the uptake of most heavy metals [150].

\subsection{Phytoremediation of organic pollutant in water}

Few aquatic plants have been generally been tested recently for removal of aquatic organic pollutant. It has been less studied compared to heavy metals mainly due to the complex properties (physical and chemical) of organic pollutants. Aquatic organic pollutants to have been remediated from aqueous solution by aquatic plants using either field and/ or hydroponic experiment include the following: chemical and biological oxygen demand (COD and BOD), nitrate, phosphate, sulphate; from agricultural chemicals including atrazine, dimethomorph, pyrimethanil, Isoproturon, glyphosate, metazachlor, chloroacetamide, flazasulfuron, terbuthylazine, 4-chloro-2-fluorophenol (4-Cl-2-FP), lactofen, cyanophos, herbicide norflurazon; from pharmaceuticals and personal care products (PPCPs) including sucralose, fluoxetine, tyramine, putrescine, cadaverine, spermidine, spermine, cefadroxil, metronidazole, trimethoprim, sulfamethoxazole, triclosan, diclofenac, naproxen, caffeine, ibuprofen, clofibric acid, sulfachlorpyridazine, oxitetracycline, chlorpyrifos, venlafaxine, 3-fluorophenol, 3-trifluoromethylphenol, phenol, ibuprofen, fluoxetine, cisplatin, linear alkylbenzene sulfonate; from dyes and toxin including textile dyes (AB113, RB198, BR46), blue dye, triacontanol, cyanotoxin 
microcystin-LR., perchlorate, toluidine Blue; and from petroleum hydrocarbons including $1 \mathrm{H}-$ benzotriazole, 4-methyl-1Hbenzotriazole, 5-methyl1Hbenzotriazole, xylytriazole, 5-chlorobenzotriazole, 3-trifluoromethylphenol, phenantherene.

Few aquatic plants to have generally been tested recently for phytoremediation of aquatic organic pollutant include M. spicatum [103, 148, 187]; Azolla filiculoides [148], Canna generalis [188], Pistia stratiotes L [131, 173, 189]; Eichornia sp. [131, 173, 190, 191]; Lemna sp. [51, 131, 192]; Salvinia sp. [131], Chara vulgaris L. [82], $H$. dubia (B1.) Backer [84], Potamogeton perfoliatus<smiles>CCOP(=S)(OCC)Oc1nc(Cl)c(Cl)cc1Cl</smiles>

Phenanthrene<smiles>Cc1cccc(C)c1N(Cn1cccn1)C(=O)CCl</smiles>

Metazachlor<smiles>CN(Cc1ccccc1)c1ccc(NN=c2n(Cl)cnn2C)cc1</smiles>

Textile dyes (BR46)<smiles>CC(C)(Oc1ccc(Cl)cc1)C(=O)O</smiles>

Clofibric acid
L. [85], Hydrilla verticillata (L.f.) Royle [193], Vallisneria natans (Lour.) Hara [193], giant reed (Arundo donax) [194], Poaceae (Phragmites australis) [194], broadleaf plantain (Plantago major L.) [222] and Ipomoea aquatica [195] while Myriophyllum aquaticum (watermilfoil) [196] and bulrush (Scirpus lacustris) [197] have also been used earlier. For remediation of municipal effluents, some of these plants in some cases have been reported to better treat wastewater than normal wastewater treatment plant [198] and combination of two or more plant increased the effectiveness of removal [199-201]. Domestic as well as industrial<smiles>c1ccc2c(c1)ccc1ccccc12</smiles>

Chlorpyrifos<smiles>CCNc1nc(Cl)nc(NC(C)(C)C)n1</smiles>

Terbuthylazine<smiles>Cc1cc(NS(=O)(=O)c2ccc(N)cc2)no1</smiles>

Sulfamethoxazole<smiles>Cc1ncc([N+](=O)[O-])n1CCO</smiles>

Metronidazole

Fig. 5. Structures of some priority and emerging pollutants to have been treated from aqueous solution with aquatic plants. Emerging pollutants are mainly from pharmaceutical and personal care products (PPCPs). PPCPs maintain chemical properties that can vary widely, usually containing a non-polar core with a polar functional moiety [184-186]. 
activities introduced over $70 \%$ organic pollutants into the aquatic environment. Bhaskara and coworkers [131] evaluated the phytoremediation potential of free floating macrophytes (Eichornia, Pistia, Salvinia and Lemna) in removing perchlorate from water. Among the plants tested, Pistia showed $63.8 \pm 4 \%(\mathrm{w} / \mathrm{v})$ removal of $5 \mathrm{mg} \mathrm{L}^{-1}$ level perchlorate in 7 days, while other plants showed low removal $(<1 \%)$. The mechanism involved in removal identified was phytoaccumulation $(18.2 \%)$ and rhizodegradation (45.68 \%). Phenol from wastewater removal by water hyacinth was demonstrated [190]. Myriophyllum spicatum L., a submerged aquatic plant was tested for the accumulation of exogenous organic pollutant linear alkylbenzenesulfonate(LAS) [103]. Results showed that plant can accumulate LAS concentration of 50$100 \mathrm{mg} / \mathrm{L}$ without showing physiological changes. Previous studies conducted by [82], [84] and [85] respectively on the uptake LAS by Chara vulgaris L., Lemna minor L., H. dubia (B1.) Backer and Potamogeton perfoliatus L. showed the potentiality of these plant in removing LAS (anionic surfactant) at moderate concentrations from water. Idris et. al., [194] evaluated and compared the removal ability of two emergent macrophytes, giant reed (Arundo donax) and Poaceae (Phragmites australis), in experimental subsurface flow, gravel-based constructed wetlands (CWs). Results showed that the BOD, total suspended solids (TSS), total phosphorus (TP), total nitrogen (TN), total ammoniacal nitrogen (TAN) and nitrate nitrogen $\left(\mathrm{NO}_{3}\right.$ ) removal in the $A$. donax and $P$. australis beds was $94 \%, 67 \%, 96 \%, 97 \%, 99.6 \%$, and effectively $100 \%$ and $95 \%, 87 \%, 95 \%, 98 \%, 99.7 \%$, and effectively $100 \%$, respectively, with no significant difference in performance between the two aquatic plants. Tran et. al., [188] using Canna generalis (a common reed and easy to grow plant both in water and wet land conditions) to remove organic pollutants such as $\mathrm{BOD}_{5}, \mathrm{TSS}, \mathrm{NH}_{4}-\mathrm{N}$ and $\mathrm{PO}_{4}-\mathrm{P}$ from wastewater in two kinds of hybrid constructed wetlands viz Facultative pond combined with free watersub-surface constructed wetlands system and horizontal subsurface flow combined with Aerobic pond system. Results showed that the ponds played an important role in the hybrid system performance and enhanced the performance of constructed wetlands. The pollutant removal efficiencies of the hybrid systems were all higher than the single constructed wetlands. The $\mathrm{BOD}_{5}, \mathrm{TSS}, \mathrm{NH}_{4}-\mathrm{N}$ and $\mathrm{PO}_{4}-\mathrm{P}$ removal efficiencies averaged $81 \%$, $85 \%, 93 \%$ and $77 \%$, respectively for the hybrid horizontal subsurface flow constructed wetlands system operated at a hydraulic loading rate of $0.075 \mathrm{~m} /$ day, while they were $89 \%, 97 \%, 97 \%$, and $68 \%$, respectively for the hybrid free water sub-surface constructed wetlands system operated at a hydraulic loading rate of $0.1 \mathrm{~m} /$ day. Yilmaz and Akbulut [199] reported a removal rate of 79 to $83 \%$ of BOD in effluent by Lemna gibba. Also, a removal rate of $94,72,63,82,82$ and 82 $\%$ respectively for biochemical oxygen demand, ammonia, total suspended solids, total nitrogen, ammonium nitrate, and phosphate by duckweed in effluent was reported [57]. Blue dye and textile dyes were removed at a rate of $59.6 \%$ and $10-96$ $\%$ respectively by $L$. minor, indicating the plant can be very useful in textile industries to remediate effluents [203, 204], supported in further study by Neag et al. [205] using Toluidine Blue dye. The usefulness of duckweed for phytoremediation of wide range of organic pollutants has been extensively reviewed recently (see ref [57]). The review covers the state of duckweed application for the remediation of diverse aquatic pollutants including organic pollutants. The removal of diverse organic pollutants from aqueous solutions has been well demonstrated in many studies reviewed. Unfortunately, to the best of our knowledge, studies concerning the removal of POPs such as PCB and OCPs from aqueous solution are lacking.

\section{Chemometrics for aquatic phytoremedia- tion}

The science of relating chemical data from chemical processes to state of system by applying mathematical or statistical methods/models is considered chemometrics [6]. It captures relationships between system variables and widely 
used in environmental analytical research [6, 207]. Information from models is viewed as simplified concepts of environmental issues. Thereby making for easy understanding by policy makers, this way decisions on environmental issues are quickly arrived at [19, 21, 207-209]. Overall, in phytoremediation studies, chemometric models are used to assess plant performance after the experimental period. Commonly used models includes; Growth rate (GR), Growth rate inhibition (\% Inhibition), Metal uptake (MU), translocation/ transfer factor (TF), bioconcentration factor (BCF), Percent metal uptake (\% MU), Removal capacity (RC) and Toxicity index (TI). These models are repeatedly used in aquatic phytoremediation studies of metals in aqueous medium [44, 48, 137, 139, $141,146,155-158,165-168,171-173,175-177$, 210-211] and can also be used in organic pollutant remediation studies. Growth rate (GR) value is an important index for predicting growth trends of plants used for remediation. GR is also referred to as relative growth rate (RGR). It was proposed by Fisher [212] and calculated using either equation (1) or (2), where $\mathrm{DB}_{\mathrm{AH}}(\mathrm{g})$ and $\mathrm{DB}_{\mathrm{BP}}(\mathrm{g})$ are the dry biomass after and before harvest, respectively, while TAH (days) and TBP (days) are the planting periods after and before harvest, measured over the study period. RGR stands for the relative growth rate $(\mathrm{mg} / \mathrm{g} / \mathrm{d}) ; \ln \left(\mathrm{m}_{1}\right)$ : logarithm of the final dry mass $(\mathrm{g}) ; \ln \left(\mathrm{m}_{0}\right)$ : logarithm of the initial dry mass $(\mathrm{g})$; $\mathrm{t}_{0}$ : initial time $(\mathrm{d}) ; \mathrm{t}_{1}$ : final time (d).

$$
G R=D B_{A H}-D B_{B P} / T_{A H}-T_{B P}
$$

$R G R=\left(\operatorname{In}\left(m_{1}\right)-\operatorname{In}\left(m_{0}\right) / t_{1}-t_{0}\right) * 1000$

The tolerance index (TI) was proposed by Wilkins [213]. It provides information regarding the tolerance of the plant to metal contamination in the solution; calculated using equation (3) as the ratio of growth rate of the plant in the solution contaminated to growth rate of the plant in the uncontaminated control solution. In the equation,
RGR is the growth rate of the plant in the solution contaminated while $\mathrm{RGR}_{\mathrm{c}}$ is the growth rate of the plant in the control solution, without contamination.

$T I=\left(R G R /{ }_{R G R_{c}}\right) * 100$

Metal uptake (MU) shows the metal content in whole plant tissue or in a selected plant part; moreover, $\mathrm{MU}$ can be calculated by using equation (4): where $\mathrm{C}_{\text {metal }}$ (mg $/ \mathrm{kg}$ or $\mathrm{mg} / \mathrm{L}$ or any acceptable units) is the metal concentration in the plant tissue, and DB $(\mathrm{g})$ is the dry biomass of the plant.

$M U(g /$ plant $)=C_{\text {metal }} * D B$

The TF shows the efficiency of the plant to transport an element from the root to the shoot; and the BCF allows for evaluating the efficiency of the plant in accumulating the chemical element, taking into account its concentration in the medium or simply the ratio of concentrations of each metal in the roots to those in the water. Both the TF and BCF can be estimated according to equations (5) and (6) respectively [44, 211].

$$
\begin{aligned}
& T F={ }^{C_{\text {metal }}} \text { in roots } / C_{\text {metal }} \text { in shoots } \\
& B C F=C_{\text {metal }} \text { in plants } / C_{\text {metal }} \text { in solution or medium }
\end{aligned}
$$

The potential for metal uptake in plant tissue is shown by percent metal uptake (\% MU); the uptake also corresponds with reduced metal concentration in solution. In addition, it can be calculated using Equation 7, where $\mathrm{C}_{\mathrm{i}}$ and $\mathrm{C}_{\mathrm{f}}$ are the initial and final metal concentrations in solution respectively.

$\% M U=\left[\left(C_{i}-C_{f}\right) / C_{i}\right] * 100$

Removal capacity (RC) indicates the potential of plants for removing metal from solution over an entire study period and can be calculated using Equation 8; where RC is the removal capacity (mg/ $\mathrm{d} / \mathrm{g}), \mathrm{C}_{\mathrm{i}}$ and $\mathrm{C}_{\mathrm{f}}$ remains as in Equation $6, \mathrm{~V}$ is the liquid volume (L), D (days) is the days, and $\mathrm{B}(\mathrm{g})$ is the mean dry biomass [49].

$R C=\left(C_{i}-C_{f}\right)-V D B$ 
Growth rate inhibition (\% Inhibition) shows the extent of inhibition to growth of plant caused by the contaminant. \% Inhibition can be calculated according equation (9), where variables remain the same as in equation (3).

\% Inhibition $=1-\left(R G R / R G R_{c}\right)$

Rhizofiltration potential (RP) is based on adsorbed heavy metals by the aqueous system and inform on the performance of the plant to accumulate or remediate contaminants using roots. $\mathrm{RP}$ is calculated as equation (10), where, $\mathrm{C}$ is concentration of heavy metal; $\mathrm{C}_{\text {leaves }}$ is concentration of heavy metal in leaves; $\mathrm{C}_{\text {roots }}$ is concentration of heavy metal in roots; $\mathrm{M}$ is dry biomass yield, $\mathrm{M}_{\text {total }}$ is leaves and root biomass yield $\left(\mathrm{g} \mathrm{DW} / \mathrm{m}^{2} / \mathrm{yr}\right)$, $\mathrm{M}_{\text {plant }}$ is the mean of plant yield ( $\mathrm{g}$ DW/m²/yr), $\mathrm{M}_{\text {root }}$ is the mean of root biomass yield (g DW/ $/ \mathrm{m}^{2} / \mathrm{yr}$ ), $\mathrm{M}_{\text {leaves }}$ is the mean of leaves biomass yield (g DW/ $\mathrm{m}^{2} / \mathrm{yr}$ ) (Rezania et al., 2016).

$R P\left(\mathrm{mg} / \mathrm{m}^{2} /\right.$ year $)=\left[\left(C_{\text {leaves }} * M_{\text {leaves }}\right)+\left(C_{\text {root }} * M_{\text {root }}\right) / M_{\text {total }}\right] * M_{\text {plant }}$

However, in a batch or continuous flow system, the accumulation or absorption may be studied by using different sorption kinetics and isotherms models such as pseudo-first-order (PFO), pseudosecond-order (PSO), Freundlich, Langmuir and Temkin. Some of the models have significant limitations e.g PFO and PSO models, which only considers adsorption step on the active sites and predicts the internal diffusion while ignoring the external diffusion. In the use of Freundlich and Langmuir isotherms models, assumption is made that there is a local equilibrium between the contaminated aqueous medium and contaminant, an assumption that may be misleading [221]. However, they have been widely used in absorption studies [215-217] and recently used in phytoremediation studies [188, 205, 218-219]. The pseudo-first order kinetic equation and pseudo second order kinetic equation simply indicates if the reaction is more inclined towards physisorption or chemisorptions depending on the closeness of regression coefficient value $\left(r^{2}\right)$ to unity (1). Furthermore, they represent the degradation rate of pollutants in the biological treatment system [188]. The kinetic equation for the pseudo-first order and pseudo second order can be calculated respectively following Equations 11 and 12: where $\mathrm{Ce}$ is the outflow concentration of metal at $t$ day (d); $C_{i}$ is the initial concentration of metal: and $\mathrm{k}$ is the first-order removal rate constant. $C_{\theta}=C_{i} * e^{-k \cdot d}$

$d / C_{\theta}=1 / k * C_{\theta}^{2}+1 / C_{\theta} * d$

Langmuir adsorption equation is the very ubiqutes linear model for monolayer adsorption, and it is used to assess the adsorption process. Langmuir model can be calculated using Equation 13: where $\mathrm{qL}$ is the quantity of metal adsorbed per unit weight of sorbent (in this case, plant) and $\mathrm{C}_{\mathrm{e}}$ is unadsorbed or outflow metal concentration remaining in water. Q corresponds to the maximum quantity of metal adsorbed per unit dry weight of the plant to form a complete monolayer on the surface and $\mathrm{k}$ is a constant associated with affinity of the binding site.

$q L=\frac{Q * k * C_{\varepsilon}}{1+k * C_{\varepsilon}}$

Freundlich model explained adsorption onto a heterogeneous surface [219] as in Equation 14: where, $\mathrm{C}_{\mathrm{e}}$ refers to solution equilibrium concentration $\left(\mathrm{mg} \mathrm{L}^{-1}\right), \mathrm{q}$ is the adsorption capacity (concentration of metal on adsorbing substrate, $\mathrm{mg} / \mathrm{kg})$, and $\mathrm{k}$ and $(1 / \mathrm{n})$ are constants connected to adsorption capacity.

$q=k * C_{\theta}^{(1 / n)}$

Temkin isotherm model corresponds to a factor which is associated with explicitly taking into the account of sorbent-adsorbate interactions. Temkin model is given in Equation 15: where, $\mathrm{q}$ is the metal concentrations in the plant biomass $(\mathrm{mg} /$ $\mathrm{kg})$, Ce corresponds to metal concentration $(\mathrm{mg} / \mathrm{L})$ remaining in outflow, $\mathrm{B}$ and $\mathrm{kt}$ are the constant 
related to adsorption process [219].

$q=\mathrm{B} \ln (\mathrm{kt})+\mathrm{B} \ln \left(\mathrm{C}_{\mathrm{e}}\right)$

The removal efficiency (RE \%) of dye from aqueous solution in a batch study can be studied by equation (16) while the amount of dye in the plant phase can be calculated using equation (17); where $\mathrm{q}_{e}$ is the amount of dye adsorbed per gram of adsorbent at equilibrium $(\mathrm{mg} / \mathrm{g}), \mathrm{C}_{0}$ and $\mathrm{C}_{\mathrm{e}}$ are the initial and equilibrium concentrations of the dye in solution $(\mathrm{mg} / \mathrm{L}) ; \mathrm{V}$ is the volume of solution $(\mathrm{mL})$; $\mathrm{m}$ is the weight of the adsorbent (plant) (g) [205].

\section{Conclusion, Knowledge gap, and Future Areas of Research}

Water resources management and protection from toxic chemicals pollution due to anthropogenic activities is of critical concern to scientist, governmental and non-governmental organizations and the general public. Phytoremediation is largely accepted and desirable to several conventional methods for the treatments of water pollution. Many aquatic plants (emerging, submerged or free flowing) have been applied extensively recently and mostly conducted using hydroponics or field experiment by constructed wetlands. Results from literature reviewed have generally established the effectiveness in remediating organic pollutants and heavy metals by aquatic plants, although heavy metals have been extensively studied than organic pollutants. Most commonly used plant include; duckweed (L. minor), water hyacinth (Eichhornia crassipes) and water lettuce (P. stratiotes), due to their ubiquitous nature, invasive mechanism, sporadic reproductive capacity, bioaccumulation potentials and resilience in polluted environment [57]. Heavy metals consider as water pulltant and must be removal from waters and reviers [223-226]. However, the removal rates are varied and mainly controlled by the physicochemical properties of the water, contaminants, plant and the experimental framework. Using modeling and interpretation of adsorption isotherms for performance assessment is particularly good and increases level of accuracy obtained from adsorption processes of contaminant on plant. Despite the promising efforts so far, there are still limitations in certain areas to demonstrate the effectiveness of the aquatic plant in phytoremediation of chemical pollutants.

\section{Knowledge gap and Future Areas of Research}

(1) A need is there for studying the plant in the face of emerging chemicals (e.g polychlorinated dibenzo- $p$-dioxins and polychlorinated dibenzofurans $(\mathrm{PCDD} / \mathrm{Fs})$ etc) which defy conventional remediation approaches for establishing acceptable remediation strategies and ecological benchmark for improvement of constructed wetlands for wastewater effluents treatment [57]. Some other priority organic pollutants such as 1,2,3-trichlorobenzene, pyrene, 1,3-Dinitrobenzene, lindane, and 2,4-Dinitrotoluene have been removed in terrestrial environment by terrestrial plant [220] while studies are lacking for their removal in aquatic environment. Therefore, there is need for an extensive study of aquatic plant for removal of these types of organic pollutants. (3) More studies are required to understand better the precise transfer pathways of pollutants and their temporal pattern, in order to pinpoint toxicity more precisely in aquatic plants. Such studies will generate an improved understanding which will help in controlling cumulative toxic effects of pollutants on plants and enhancing the role of aquatic plants as a vital ecological based bioremediation agent for water pollution.

\section{Conflicts of interest}

The researchers declares no conflicts of interest regarding the publication of this manuscript

\section{References}

[1] United States Geological Survey (USGS), Ground Water and Surface Water: A Single Resource, Circular, (1998) 1139.

[2] T. Zhang, Q. Lu, C. Su C., Y. Yang, D. Hu, Q. Xu, Mercury induced oxidative stress, DNA damage, and activation of antioxidative system and Hsp70 induction in duckweed (Lemna minor), Ecotox. Environ. Safe., 143 (2017) 46-56. 
[3] C. Jiang, H. Chen, Y. Zhang, H. Feng, M.A. Shehzad, Y. Wang, T. Xu, Complexation electrodialysis as a general method to simultaneously treat wastewaters with metal and organic matter, Chem. Eng. J., 348 (2018) 952-959.

[4] M.N.V Prasad, Aquatic Plants for Phytotechnology, (2006) 259-274.

[5] C.F. Carolin, P.S. Kumar, A. Saravanan, G.J. Joshiba, $\mathrm{Mu}$ Naushad, Efficient techniques for the removal of toxic heavy metals from aquatic environment: a review, J. Environ. Chem. Eng., 5 (2017) 27822799.

[6] C.E. Enyoh, A.W. Verla, N.J. Egejuru, pH variations and chemometric assessment of borehole water in Orji, Owerri Imo State, Nigeria, J. Environ. Anal. Chem., 5 (2018) 1-9.

[7] CDC, Global WASH Fast Facts. Global Water, Sanitation, \& Hygiene (WASH), (2016). https:// www.cdc.gov/healthywater/global/wash_statistics. html Accessed 30/7/2019.

[8] World Health Organization and UNICEF, Meeting the MDG Drinking Water and Sanitation Target: The urban and rural challenge of the decade, 2006, 1-47. https://www.who.int/water_sanitation health/monitoring/jmpfinal.pdf

[9] Z. J. Xu, Y. Cao, Y. Zhang, Z. Yuan, Z. Lou, X. Xu, X. Wang, A review of functionalized carbon nanotubes and graphene for heavy metal adsorption from water: preparation, application, and mechanism, Chemosphere, 195 (2018) 351-364.

[10] L. K. Charity, V. A. Wirnkor, A.C. Emeka, A.A. Isioma, C.E. Ebere, Health risks of consuming untreated borehole water from uzoubi umuna orlu, Imo State Nigeria, J. Environ. Anal. Chem., 5 (2018) 250-264.

[11] A. Bhatnagar, M. Sillanpaa, Utilization of agroindustrial and municipal waste materials as potential adsorbents for water treatment, Chem. Eng. J., 157 (2010) 277-296.

[12] E. Padilla-Ortega E., R. Leyva-Ramos, J.V. FloresCano, Binary adsorption of heavy metals from aqueous solution onto natural clays, Chem. Eng. J., 225 (2013) 535-546.

[13] A.W. Verla, E. N. Verla, C.E. Amaobi, C.E. Enyoh, Water pollution scenario at river uramurukwa flowing through owerri metropolis, Imo State, Nigeria, Inter. J. Appl. Sci. Res., 3 (2018) 40-46.

[14] K. H. Vardhan, S. K. Ponnusamy, C.P. Rames, A review on heavy metal pollution, toxicity and remedial measures: Current trends and future perspectives, J. Mole. Liq., 290 (2019) 111-197.

[15] L. West, World Water Day: A Billion people worldwide lack safe drinking water, 2018. http:// environment.about.com/od/environmentalevents/a/ waterdayqa.htm

[16] D.H. Pink, Investing in Tomorrow's Liquid Gold., 2019. $\quad$ https://web.archive.org/ web/20060423172532/https://finance.yahoo.com/ columnist/article/trenddesk/3748

[17] K. Kelland, Study links pollution to millions of deaths worldwide, 2017. https://www.reuters. com/article/us-health-pollution/study-linkspollution-to-millions-of-deaths-worldwideidUSKBN1CO39B .

[18] L. Järup, Hazards of heavy metal contamination. Br. Med. Bull. 68 (2003) 167-182.

[19] E.N. Verla, A.W. Verla, C.E. Enyoh, Pollution assessment models of soils in portharcourt city, rivers state, Nigeria. World News Nat. Sci., 12 (2017) 1-23.

[20] A. W. Verla, C. E. Enyoh, E. N. Verla, Microplastics, an emerging concern: a review of analytical techniques for detecting and quantifying microplatics, Anal. Method. Environ. Chem. J., 2 (2019) 15-32. https://doi.org/10.24200/amecj

[21] A.W. Verla, E.N. Verla, C.E. Enyoh, K. Leizou, N.O. Peter, Using physicochemical properties in assessment of river water for consumption and irrigation in Nigeria, Eurasian J. Anal. Chem., 5(2019) 14-23.

[22] R. S. Boyd, Heavy metal pollutants and chemical ecology: exploring new frontiers, J. Chem. Ecol., 36 (2010) 46-58.

[23] LH. Gade, Highly polar metal-metal bonds in "early-late" heterodimetallic complexes. Angew. Chem. Int. Ed., 39 (2000) 2658-2678.

[24] K.V. Ragnarsdottir, D. Hawkins, Trace metals in soils and their relationship with scrapie occurrence, Geochim. Cosmochim. Acta, 69 (2005) 196-196.

[25] M.I. Lone, Z. He, P.J. Stoffella, X. Yang, Phytoremediation of heavy metal polluted soils and water: Progresses and perspectives, J. Zhej. Uni. Sci. B, 9 (2008) 210-220.

[26] J. Yabe, I. Mayuni, U. Takashi, Current levels of heavy metal pollution in Africa. J. Vet. Med. Sci., 72 (2010) 1257-1263.

[27] J.D. Appleton, M.R. Cave, B. Palumbo-Roe, J. Wragg, Lead bioaccessibility in top soils from lead mineralization and urban domains, UK. Environ. 
Pollut., 178 (2013) 278-287.

[28] J.B. Diatta, W. Grzebisz, Simulative evaluation of $\mathrm{Pb}, \mathrm{Cd}, \mathrm{Cu}$, and $\mathrm{Zn}$ transfer to humans: The case of recreational parks in Poznan, Poland. Pol. J. Environ. Stud., 20 (2011) 1433-1440.

[29] C. E. Enyoh, A.W. Verla, E.N. Verla, Uptake of microplastics by plant: a reason to worry or to be happy, World Sci. News, 131 (2019) 256-267.

[30] EEA report, Heavy metal emissions, Eur. Environ. Agency, (2019).

[31] M. van het Bolcher, H. Denier van der Gon, B.J. Groenenberg, I. Ilyin, G.J. Reinds, J. Slootweg, O. Travnikov, A. Visschedijk, W. de Vries, Heavy metal emissions, depositions, critical loads and exceedances in Europe-J.P. Hettelingh - J. Sliggers. VROM-DGM, Directie Klimaatverandering en Industrie, IPC 650, (2006) P.O. Box 20951, 2500 EZ Den Haag, Netherlands.

[32] Wang F., Kuehr R., Ahlquist D., Li J. E-waste in China: A country report; United Nations University, (2019). https://collections.unu.edu/ eserv/UNU:1624/ewaste-in-china.pdf.

[33] W. Barabasz, D. Albinska, M. Jaskowska, J. Lipiec, Ecotoxicology of aluminium. Pol. J. Environ. Stud., 11 (2002) 199-203.

[34] R. Grazuleviciene, R. Nadisauskiene, J. Buinauskiene, T. Grazulevicius, Effects of elevated levels of manganese and iron in drinking water on birth outcomes, Pol. J. Environ. Stud., 18 (2009) 819-825.

[35] M. Jaishankar, T. Tseten, N. Anbalagan, B.B. Mathew, K.N. Beeregowda Toxicity, mechanism and health effects of some heavy metals. Interdiscip. Toxicol., 7 (2014) 60-72.

[36] S. Martin, W. Griswold, Human health effects of heavy metals, Environ. Sci. Tech. Briefs Citizens 15 (2009) 1-6.

[37] C. B. de Souza, G.R. Silva, Phytoremediation of effluents contaminated with heavy metals by floating aquatic macrophytes species. Intertech Open book, (2019). http://dx.doi.org/10.5772/ intechopen.83645

[38] N. Sooksawat, M. Meetam, M. Kruatrachue, P. Pokethitiyook, K. Nathalang, Phytoremediation potential of charophytes: bioaccumulation and toxicity studies of cadmium, lead and zinc, J. Environ. Sci., 25(3) (2013) 596-604

[39] F.E.C. Sneller, L.M. van Heerwaarden, H. Schat, Toxicity, metal uptake, and accumulation of phytochelatins in silene vulgaris exposed to mixtures of cadmium and arsenate, Environ.
Toxicol. Chem., 19 (2000) 2982-2986.

[40] G. Brunetto, Heavy metals in vineyards and orchard soils. Revista Brasileira de Fruticultura, Jaboticabal. 39 (2017) e-263.

[41] F.V. de Campos, J. A. de Oliveira, A.A. da Silva, C. Ribeiro, F. F. dos Santos, Phytoremediation of arsenite-contaminated environments: is Pistia stratiotes L. a useful tool, Ecological Indicators 104 (2019) 794-801

[42] S. Jasrotia, K. Arun, M. Aradhana, Performance of aquatic plant species for phytoremediation of arsenic-contaminated water, Appl. Water Sci. 7 (2017) 889-896.

[43] S.H. Hasan, M. Talat, S. Rai, Sorption of cadmium and zinc from aqueous solutions by water hyacinth (Eichchornia crassipes), Bioresour. Technol. 98 (2007) 918-928

[44] L.Q. Ma, K.M. Komar, C. Tu, W. Zhang, Y. Cai, E.D. Kennely, A fern that hyperaccumulates arsenic, Nature, 409 (2001) 579.

[45] W. Samuel, B. Richard, E. Helen, L. Darkwah, Assessment of typha capensis for the remediation of soil contaminated with $\mathrm{As}, \mathrm{Hg}, \mathrm{Cd}$ and $\mathrm{Pb}$, Environ. Monit. Assess., 191 (2019) 346. https:// doi.org/10.1007/s10661-019-7484-2

[46] S. Radic, M. Babic, D. S`kobic, V. Roje, B. PevalekKozlina, Ecotoxicological effects of aluminium and zinc on growth and antioxidants in Lemna minor L, Ecotoxicol. Environ. Safe. 73 (2010) 336-342.

[47] J. Razinger, M. Dermastia, J.D. Koce, A. Zrimec, Oxidative stress in duckweed (Lemna minor L.) caused by short-term cadmium exposure, Environ. Pollut. ,153 (2008) 687-694.

[48] H. Li, F. Cheng, A. Wang, T. Wu, Cadmium removal from water by hydrophytes and its toxic effects, Proceeding of the international symposium of phytoremediation and ecosystem health, Hangzhou, China, (2005).

[49] T. Sricoth, W. Meeinkuirt, P. Saengwilai, J. Pichtel, P. Taeprayoon, Aquatic plants for phytostabilization of cadmium and zinc in hydroponic experiments, Environ. Sci. Pollut. Res. 25 (2018) 14964-14976. https://doi.org/10.1007/s11356-018-1714-y

[50] C. Jung-Chun, W. Kai-Sung, H. Chen, C. Lu, L. Huang, H. Li, T. Peng, S. Chang, Phytoremediation of $\mathrm{Cr}$ (III) by Ipomonea aquatica (water spinach) from water in the presence of EDTA and chloride: Effects of Cr speciation, Bioresour. Technol., 101 (2010) 3033-3039.

[51] M. Marcia, A. Christiane, R. Chafim, S. Jonatas, 
Technical challenges and social, economic and regulatory barriers to phytoremediation of contaminated soils, Rev. Bras. Ciênc. Solo., 35 (2011) 1-11.

[52] G.A Leao, J.A. de Oliveira, R.T.A. Felipe, F.S. Farnese, G.S. Gusman, Anthocyanins, thiols, and antioxidant scavenging enzymes are involved in Lemna gibba tolerance to arsenic, J. Plant Interact., 9 (2014) 143-151.

[53] K. Jayakumar, M. Rajesh, L. Baskaran, P. Vijayarengan, Changes in nutritional metabolism of tomato (Lycopersicon esculantum Mill.) plants exposed to increasing concentration of cobalt chloride, Int. J. Food Nut. Safe., 4 (2013) 62-69.

[54] K. Jayakumar, C. A. Jaleel, M. M. Azooz, Phytochemical changes in green gram (Vigna radiata) under cobalt stress, Global J. Mol. Sci., 3 (2008) 46-49.

[55] K. Jayakuma, C. A. Jaleel, and P. Vijayarengan, Changes in growth, biochemical constituents, and antioxidant potentials in radish (Raphanus sativus L.) under cobalt stress, Turkish J. Biol., 31, 3 (2007) 127-136.

[56] W. Drost, M. Matzke, T. Backhaus, Heavy metal toxicity to Lemna minor: studies on the time dependence of growth inhibition and the recovery after exposure, Chemosphere, 67 (2007) 36-43.

[57] O. E. Abraham, F.D. Sikoki, E. O. Nwachukwu, Application of common duckweed (Lemna minor) in phytoremediation of chemicals in the environment: state and future perspective, Chemosphere 223 (2019) 285-309.

[58] A.W. Verla, E.N. Verla, C.E. Enyoh, Petroleum hydrocarbons and heavy metals risk of consuming fish species from oguta lake, Imo State, Nigeria, 6th International Science Congress, ISCA-ISC-8EVS08-Poster, Pune, Maharastra, India, (2016).

[59] L. E. Okoumassoun, C. Brochu, C. Deblois, S. Akponan, M. Marion, D. Averill-Bates, F. Denizeau, Vitellogenin in tilapia male fishes exposed to organochlorine pesticides in Ouémé river in republic of Benin, Sci. Total Environ., 299 (2002) 163-172.

[60] H.B. Moon, H.S. Kim, M. Choi, H.G. Choi, Intake and potential health risk of polycyclic aromatic hydrocarbons associated with seafood consumption in Korea from 2005 to 2007. Arch. Environ. Contam. Toxicol., 58(1) (2010) 214-221.

[61] I. Tolosa, S.J. de Mora, S.W. Fowler, J.P. Villeneuve, J. Bartocci, C. Cattini, Aliphatic and aromatic hydrocarbons in marine biota and coastal sediments from the Gulf and the Gulf of Oman, Mar. Pollut. Bull.,50 (2005) 1619-1633.

[62] M.A. Al-kahtani, Accumulation of Heavy metals in Tilapia fish (Oreochromisniloticus) from Alkhadoud spring, Al-Hassa, Saudi Arabia, Am. J. Appl. Sci., 6 (2009) 2024- 2029.

[63] P. A. Sreedevi, B. Suresh, B. Siraramkrishna, B. Prebhavarhi, K. Radhakrishriaiah, Bioaccumulation of Nickel in organs of the fresh water fish, Cyprinocarpio and the fresh water mussel Lamethdeimarginalis under lethal and sublethal nickel stress, Chemosphere, 24 (1992) 29-36.

[64] S.P. Kumar, J.K.P. Edward, Assessment of metal concentration in the sediment cores of Manakudy estuary, south west coastal of India, Indian J. Mar. Sci., 38 (2009) 235-248.

[65] C.E. Enyoh, E.A. Ihionu, A. W. Verla, N.P. Ebosie, Physicochemical Properties of Palm Oil and Soil from Ihube Community, Okigwe, Imo State, Nigeria, Int. Letter. Nat. Sci., 62 (2017) 35-49.

[66] A.W. Verla, E. N. Verla, C.M. Ajero, K.C. Lele, N.O. Stellamarris, C.E. Enyoh, Biomonitoring of heavy metals in blood and urine of African children from Owerri Metropolis, Eastern Nigeria, J. Chem. Health Risks, 9 (2019) 11-26.

[67] ATSDR, Toxicological Profile for Cadmium. CAS\#: 7440-43-9. (2012) https://www.atsdr.cdc. gov/toxprofiles/tp.asp? $\mathrm{id}=48 \& \mathrm{tid}=15$

[68] ATSDR, Toxicological Profile for Chromium. CAS\#: 7440-47-3 (2012). https://www.atsdr.cdc. gov/toxprofiles/tp.asp?id=62\&tid $=17$

[69] ATSDR, Toxicological Profile for Cobalt. CAS\#: 7440-48-4 (2004). https://www.atsdr.cdc.gov/ toxprofiles $/$ tp.asp? $\mathrm{id}=373 \&$ tid $=64$

[70] ATSDR, Toxicological Profile for Copper. CAS\#: 7440-50-8 (2004). https://www.atsdr.cdc.gov/ toxprofiles/tp.asp? $\mathrm{id}=206 \& \mathrm{tid}=37$

[71] ATSDR, Toxicological Profile for Nickel. CAS\# 7440-67-2. (2005). https://www.atsdr.cdc.gov/ toxprofiles $/$ tp.asp? $\mathrm{id}=245 \& \mathrm{tid}=44$

[72] ATSDR, Toxicological Profile for Lead. CAS\# 7439-92-1. (2019). https://www.atsdr.cdc.gov/ ToxProfiles $/$ tp.asp? $\mathrm{id}=96 \& \mathrm{tid}=22$

[73] ATSDR, Toxicological Profile for Zinc. CAS\#: 7440-66-6 (2005). https://www.atsdr.cdc.gov/ toxprofiles $/$ tp.asp? $\mathrm{id}=302 \& \mathrm{tid}=54$

[74] N.D. Bedding, A.E. McIntyre, R. Perry, J.N. Lester, Organic contaminants in the aquatic environment I, Sources and occurrence, Sci. Total Environ., 25 
(1982) 143-167.

[75]A.G. Burton, R. Pitt, Stormwater Effects Handbook: A Toolbox for Watershed Managers, Scientists, and Engineers, New York: CRC/Lewis Publishers, Chapter 2, (2001).

[76] Anonymous, Text of the stockholm convention, Amended in 2009, 2011, 2013 and 2015, (2008). http://chm.pops.int/TheConvention/Overview/ TextoftheConvention/tabid/2232/Default.aspx

[77] A. David, M. Christiana, D. Godfred, J.W. Johan, S. Bjame, C.A. Robert, Uptake of antibiotics from irrigation water by plants, Chemosphere, 157 (2016) 107-114.

[78] E.M. Dettenmaier, W.J. Doucette, B. Bugbee. Chemical hydrophobicity and uptake by plant roots, Environ. Sci. Technol., 43 (2009) 324-329.

[79] M. Trapp, C. McFarlane, Plant contamination, Lewis Publisher, Boca Raton (1995).

[80] M.N.V. Prasad, A State-of-the-Art report on bioremediation, its applications to contaminated sites in India, ministry of environment \& forests, government of India, Indian national science academy (2011). http://soilhealth. ucdavis.edu/application/files/2015/4207/9078/ BioremediationBook.pdf

[81] Z. Cheng, F. Yao, L. Yuan-wang, C. Hui-qing, L. Zhao-jun, X. Jian-ming, Uptake and translocation of organic pollutants in plants: A review, J. Integr. Agric., 16 (2017) 1659-1668.

[82] N. Liu, Z. Wu, Toxic effects of linear alkylbenzene sulfonate on Chara vulgaris L, Environ. Sci. Pollut. Res., 25 (2018) 4934-4941.

[83] Z. Wang, J. Zhang, L. Song, E. Li, X. Wang, B. Xiao, Effects of linear alkylbenzene sulfonate on the growth and toxin production of Microcystis aeruginosa isolated from Lake Dianchi, Environ. Sci. Pollut. Res., 22 (2015) 5491-5499.

[84] Z. Wu, D. Yu, J. Li, G. Wu, X Niu, Growth and antioxidant response in Hydrocharis dubis (B1.) Backer exposed to linear alkylbenzene sulfonate, Ecotoxic., 19: (2010) 761-769.

[85] J. Zhou, Z. Wu, D. Yu, Y. Pang, H. Cai, Y. Liu, Toxicity of linear alkylbenzene sulfonate to aquatic plant Potamogeton perfoliatus L, Environ. Sci. Pollut. Res., 25 (2018) 32303-32311.

[86] W. Wang, R. Li, Q. Zhu, X. Tang, Q. Zhao, Transcriptomic and physiological analysis of common duckweed Lemna minor responses to $\mathrm{NH}^{4+}$ toxicity, BMC Plant Biol., 16:92 (2016)1-13.

[87] S. Bayen, G.O. Thomas, H.K. Lee, E.L.Yong, J.P.
Obbard, Occurrence of PCBs and PBDEs in green mussels (Perna viridis) sampled from Singapore's coastal waters, Environ. Toxicol. Chem., 22 (2003) 2432-2437.

[88] S. Bayen, Y.H. Gong, H.S. Chin, H. K. Lee, E.L. Yong, E. L., J.P. Obbard, Determination of polybrominated diphenyl ethers (PBDEs) in marine biological tissues using microwave assisted extraction (MAE), J. Chromatogr. A, 1035 (2004) 291-294.

[89] . Bayen, Y.H. Gong, H.S. Chin, H. K. Lee, E.L. Yong, E. L., J.P. Obbard, Organochlorine pesticides and heavy metals in green mussel, Perna viridis, in Singapore, Water Air Soil Pollut., 155 (2004) 103-116.

[90] Bayen, Y.H. Gong, H.S. Chin, H. K. Lee, E.L. Yong, E. L., J.P. Obbard,. Androgenic and estrogenic response of green mussel extracts from Singapore's coastal environment using a human cellbased bioassay, Environ. Health Perspect., 112 (2004) 1467-1471.

[91] S. Karups, S. Annamalai, J.P. Obbard, Barnacle, attached to the bottle-nose dolphin, Xenobalanus globicipitis (Cirripedia, Coronulidae), Tursiops truncatus (Mammalia, Cetacea) on the southeastern coast of India, J. Crustaceana, 77 (2004) 879-882.

[92] S. Karups, S. Annamalai, J.P. Obbard, Organochlorine residues in marine mammals from the southeast coast of India, Chemosphere, 60 (2004) 891-897.

[93] D. Yahia, E.E. Elsharkawy, Multi pesticide and PCB residues in Nile tilapia and catfish in Assiut city, Egypt, Sci. Total Environ., 466- 467 (2014) 306-314.

[94] Q. Q. Li , A. Loganath, Y.S. Chong, J. Tan, J.P. Obbard, Persistent Organic Pollutants and Adverse Health Effects in Humans, J. Toxicol. Environ. Health Part A, 69 (2006) 1987-2005

[95] S. Safe, Toxicology, structure-function relationship, and human and environmental health impacts of polychlorinated biphenyls: progress and problems, Environ. Health Perspect., 100 (1993) 259-268.

[96] K. Frische, J. Schwarzbauer, M. Ricking, Structural diversity of organochlorine compounds in groundwater affected by an industrial point source, Chemosphere., 81 (2010) 500-8.

[97] W. Brack, H.J. Klamer, M. López de Alda, D. Barceló, Effect-directed analysis of key toxicants in European river basins a review, Environ Sci. Pollut. Res. Int., 14 (2007) 30-38. 
[98] E. T. Pawłowicz, Organic pollution of water and human health, Health Problems Civilization, 1 (2017) 32-39.

[99] D. Skutlarek, M. Exner, H. Färber, Perfluorinated surfactants in surface and drinking waters, Environ. Sci. Pollut. Res. Int., 13 (2006) 299-307.

[100] G.C. Windham, D. Lee, P. Mitchell, M. Anderson, M. Petreas, B. Lasley, Exposure to organochlorine compounds and effects on ovarian function. Epidemiol., 16 (2005) 182-190.

[101] R. W. Bretveld, M. Hooiveld, G.A. Zielhuis, A. Pellegrino, I.A. van Rooij, N. Roeleveld, Reproductive disorders among male and female greenhouse workers. Reprod. Toxicol., 25 (2008) 107-114.

[102] J. P. Arrebola, H. Belhassen, F. Artacho-Cordón, R. Ghali, H. Ghorbel, H. Boussen, F. PerezCarrascosa, J. Expósito, A. Hedhili, N. Olea, Risk of female breast cancer and serum concentrations of organochlorine pesticides and polychlorinated biphenyls: a case-control study in Tunisia, Sci. Total Environ., 520 (2015) 106-113.

[103] Y. Liua, N. Liua, Y. Zhoub, F. Wangb, Y. Zhangb, Z. Wua, Growth and Physiological Responses in Myriophyllum spicatum L. Exposed to Linear Alkylbenzene Sulfonate, (2019). Doi:10.1002/ etc. 4475

[104] UNEP (Undated), Phytoremediation: An environmentally sound technology for pollution prevention, control and redmediation, an introductory guide to decision-makers, newsletter and technical publications freshwater management series No. 2, United Nations environment programme division of technology, industry, and economics, (2019). http://www.unep.or.jp/Ietc/ Publications/Freshwater/FMS2/1.asp , Assessed 18/8/2019

[105] R.R. Brooks, M.F. Chambers, L.J. Nicks, B.H. Robinson, Phytomining, Trends Plant Sci., 3 (1998) 359-362.

[106] Ernst, W.H.O., Bioavailability of heavy metals and decontamination of soil of soil plants, App. Geochem., 11 (1996) 163-167.

[107] A.W. Erakhrumen, Phytoremediation: an environmentally soundtechnology for pollution prevention, control andremediation in developing countries, Edu. Res. Review, 2 (2007) 151-156.

[108] M. Ghosh, S.P. Singh, A review on phytoremediation of heavy metals and utilization of its byproducts, Appl. Ecol. Environ. Res., 3 (2005) 1-18.
[109] USEPA, Treatment technologies for site cleanup: annual status report (12th Edition), Tech. Rep. EPA-542-R-07-012, Solid Waste and Emergency Response (5203P), Washington, DC, USA, (2007).

[110] M. Kuperberg, G. Banuelos, R.L. Chaney, M. Coia, S. Dushenkov, G. Hulet, R. Kristich, M. Kucharski, M. Lasat, S. Lee, Y.M. Li, K. Rose, N. Terry, Removal from soil report, Proceedings from the workshop on phytoremediation of inorganic contaminants, Argonne Natl. Lab, Chicago, IL., (1999).

[111] M.M. Lasat, Phytoextraction of toxic metals: a review of biological mechanisms, J. Environ. Quality, 31 (2002) 109-120.

[112] J. Vymazal, The use of hybrid constructed wetlands for wastewater treatment with special attention to nitrogen removal: A review of recent development, Water Res., 47 (2013) 4795-4811.

[113] Y.K. Kumar, N. Gupta, A. Kumar, L.M. Reece, N. Singh, S. Rezania, S. A. Khan, Mechanistic understanding and holistic approach of phytoremediation: A review on application and future prospects, Ecol. Eng., 120 (2018) 274-298.

[114] P.J.C. Favas, J. Pratas, N. Rodrigues, R. D’Souza, M. Varun, M.S. Paul, Metal (loid) accumulation in aquatic plants of a mining area: potential for water quality biomonitoring and biogeochemical prospecting, Chemosphere, 194 (2018) 158-170.

[115] USDA, The PLANTS Database, National Plant Data Team, NRCS, United States Department of Agriculture, Greensboro, NC 27401-4901 USA, (2018). http://plants.usda.gov

[116] E. Aksorn, P. Visoottiviseth, Selection of Suitable Emergent Plants for Removal of Arsenic from Arsenic Contaminated Water, Sci. Asia, 30 (2004) 105-113.

[117] M.N.V. Prasad, M. Greger, P. Aravind, Biogeochemical cycling of trace elements by aquatic and wetland plants: relevance to phytoremediation. In: Prasad MNV, Sajwan KS, Naidu R (eds), Trace elements in the environment: Biogeochemistry, Biotechnology and Bioremediation. CRC Press, Florida, USA, Taylor and Francis, Chap 24, 443474 (2005).

[118] M.N.V. Prasad, M. Greger, B.N. Smith, Aquatic macrophytes, in metals in the environment: Analysis by biodiversity, Prasad MNV (ed) Marcel Dekker Inc., New York, 259 (2001).

[119] T.G. Sors, D.R. Ellis, D.E. Salt, Selenium uptake, translocation, assimilation and metabolic fate in plants, Photosynth. Res., 86 (2005) 373-389. 
[120] X.Yu, J. Gu, Phyto-transport and assimilation of selenium, plant-based remediation processes, Springer, 159-175 (2013). https://doi. org/10.1007/978-3-642-35564-6_9

[121] J. Kania, M. Hannigan, T.E. Kujundzic, Phytoremediation, Halifax, Canada, 1-7 (2002). http://www.colorado.edu/MCEN/EnvTox/ Phytoremedy.pdf

[122] HCSM, Constructed Stormwater Wetlands, Pervious Pavement. Horry County Stormwater Management,(2016). http://stormwater. horrycounty.org/Home/LowImpactDevelopment/ ConstructedStormwaterWetlands.aspx . Accessed 6/9/2019.

[123] D.C. Adriano, W.W. Wenzel, J. Vangronsveld, N.S. Bolan, Role of assisted natural remediation in environmental cleanup, Geoderma, 122 (2004) 121-142.

[124] M.N.V. Prasad, Heavy metal stress in plants: from biomolecules to ecosystems, Narosa Publishing House, New Delhi, 2nd Ed., 462, 2004.

[125] P. K. Rai, Heavy metal pollution in aquatic ecosystems and its phytoremediation using wetland plants: An ecosustainable approach, I. J. Phytoremed., 10 (2008) 133-160.

[126] I.T. Cousins, D. Mackay, Strategies for including vegetation compartments in multimedia models, Chemosphere, 44 (2001) 643-654.

[127] J. Fismes, G.C. Perrin, B.P. Empereur, J.L. Morel, Soil-to-root transfer and translocation of polycyclic aromatic hydrocarbons by vegetables grown on industrial contaminated soils, J. Environ. Quality, 31 (2002) 1649-1656.

[128] C. Moeckel, G. Thomas, J.L. Barber, K.C. Jones, Uptake and storage of PCBs by plant cuticles. Environ. Sci. Technol., 42 (2008)100-105.

[129] J. Y. Liu, L.S. Jerald, Uptake and translocation of lesser-chlorinated polychlorinated biphenyls (PCBs) in whole hybrid poplar plants after hydroponic exposure, Chemosphere, 73 (2008)1608-1616.

[130] X. Hua, M. Li, Y. Su, D. Dong, Z. Guo, D. Liang, The degradation of linear alkylbenzene sulfonate (LAS) in the presence of light and natural biofilms: The important role of photosynthesis, J. Hazard. Mater., 229 (2012) 450-454.

[131] K. Bhaskaran, V. Nadaraja, S. Tumbath, B. Shah, G. P. Veetil, Phytoremediation of perchlorate by free floating macrophytes, J. Hazard. Mater., 260 (2013) 901-906.
[132] Öztürk M, Ashraf M, Aksoy A, Ahmad M S A, Hakeem K R, eds., Plants, pollutants and remediation, Springer Netherlands, USA, 241-305, 2015.

[133] Y. Uysal, F. Taner, Effect of pH, temperature, and lead concentration on the bioremoval of lead from water usingLemna minor, Int. J. Phytoremed., 11 (2009) 591-608.

[134] Y. Uysal, Removal of chromium ions from wastewater by duckweed, Lemna minor L. by using a pilot system with continuous flow, J. Hazard. Mater., 263 (2013) 486-492.

[135] V.A. Nzengung, C.H. Wang, G. Harvey, Plantmediated transformation of 329 perchlorate into chloride, Environ. Sci. Technol,. 33 (1999) 14701478.

[136] S. Alvarado, M. Guédez, M.P. Lué-Merú, G. Nelson, A. Alvaro, A.C. Jesús, Z. Gyula, Arsenic removal from waters by bioremediation with the aquatic plants Water Hyacinth (Eichhornia crassipes) and Lesser Duckweed (Lemna minor), Bioresour. Technol., 99 (2008) 8436-8440.

[137] M. Sasmaz, E. Obek, A. Sasmaz, Bioaccumulation of uranium and thorium by Lemna minor and Lemna gibba in $\mathrm{Pb}-\mathrm{Zn}-\mathrm{Ag}$ tailing water, Bull. Environ. Contam. Toxicol., 97 (2016) 832-837.

[138] A. Sandhi, T. Landberg, M. Greger, Phytofiltration of arsenic by aquatic moss (Warnstorfia fluitans), Environ. Pollut., 237 (2017) 1098-1105.

[139] F. Tufaner, Post-treatment of effluents from UASB reactor treating industrial wastewater sediment by constructed wetland, Environ. Technol., (2018) accepted manuscript.

[140] B. Boonyapookana, E. S. Upatham, M. Kruatrachue, P. Pokethitiyook, S. Singhakaew, Phytoaccumulation and Phytotoxicity of Cadmium and Chromium in Duckweed Wolffia globose, Int. J. Phytoremed., 4 (2002) 87-100.

[141] D. Baldantoni, A. Alfani, P. Di Tommasi, G. Bartoli, A. V. De Santo, Assessment of macro and microelement accumulation capability of two aquatic plants, Environ. Pollut.,130 (2004) 149156.

[142] X. Lu, M. Kruatrachue, P. Pokethitiyook, K. Homyok, Removal of cadmium and zinc by water hyacinth, Sci. Asia, 30 (2004) 93-103.

[143] A. Basile, S. Sorbo, B. Conte, R.C. Cobianchi, F. Trinchella, C. Capasso, V. Carginale, Toxicity, Accumulation, and removal of heavy metals by three aquatic macrophytes, Int. J. Phytorem., 14 
(2012) 374-387.

[144] D. Chaudhuri, A. Majumder, A.K. Misra, K. Bandyopadhyay, Cadmium removal by Lemna minor and Spirodela polyrhiza, Int. J. Phytorem., 16 (2013) 1119-1132.

[145] F. Hadi, A. Ahmad, N. Ali, Cadmium (Cd) removal from saline water by Veronica anagallis and Epilobium laxum in hydroponic system, Sci. Res., 14 (2014) 935-944.

[146] H. Vaseem, T.K. Banerjee, Efficacy of phytoremediation technology in decontaminating the toxic effluent released during recovery of metals from polymetallic sea nodules, Int. Aquat. Res., 7 (2015) 17-26.

[147] E.Ü. Tunca, K. Terzioğlu, H. Türe, The effects of alginate microspheres on phytoremediation and growth of Lemna minor in the presence of $\mathrm{Cd}$, Chem. Ecol., 33 (2017) 1-17.

[148] E. Amare, F. Kebede, W. Mulat, Wastewater treatment by Lemna minor and Azolla filiculoides in tropical semiarid regions of Ethiopia, Ecolog. Eng., 120, (2018) 464-473.

[149] Q. Lu, T. Zhang, W. Zhang, C. Su, Y. Yang, D. Hu, Q. X u, Alleviation of cadmium toxicity in Lemna minor by exogenous salicylic acid, Ecotoxicol. Environ. Saf., 147, (2018) 500-508.

[150] A. Shirinpur-Valadi, A. Hatamzadeh, S. Sedaghathoor, Study of the accumulation of contaminants by Cyperus alternifolius, Lemna minor, Eichhornia crassipes, and Canna $\times$ generalis in some contaminated aquatic environments, Environ. Sci. Pollut. Res., 26 (2019) 21340-21350.

[151] M.A. Maine, N.L. Sune, S.C. Lagger, Chromium bioaccumulation: comparison of the capacity of two floating aquatic macrophytes, Water Res., 38 (2004) 1494-1501.

[152] R. Bennicelli, Z. Stępniewska, A. Banach, K. Szajnocha, J. Ostrowski, The ability of Azolla caroliniana to remove heavy metals (Hg(II), Cr(III), $\mathrm{Cr}(\mathrm{VI}))$ from municipal waste water, Chemosphere J., 55 (2004) 141-146.

[153] P. Miretzky, A. Saralegui, C.A. Fernandez, Aquatic macrophytes potential for the simultaneous removal of heavy metals (Buenos Aires, Argentina), Chemosphere J., 57 (2004) 997-1005.

[154] T. P. Choo, C. K. Lee, K. S. Low, O. Hishamuddin, Accumulation of chromium (VI) from aqueous solutions using water lilies (Nymphaea spontanea), Chemosphere J., 62 (2006) 961-967.

[155] C. Bragato, H. Brix, M. Malagoli, Accumulation of nutrients and heavy metals in Phragmites australis Steudel and Bolboschoenus maritimus (L.) Palla in a constructed wetland of the Venice lagoon watershed, Environ. Pollut., 144 (2006) 967-975.

[156] P.K. Rai, Phytoremediation of heavy metals in a tropical impoundment of industrial region, Environ. Monit. Assess., 165 (2010) 529-537.

[157] J. Augustynowicza, M. Grosickia, E. HanusFajersk, M. Lekka, A. Waloszek, H. Kołoczek, Chromium(VI) bioremediation by aquatic macrophyte Callitriche cophocarpa Sendtn. Chemosphere, 79 (2010) 1077-1083.

[158] E. Üçüncü, E, Tunca, S. Fikirdeşici, A.D. Özkan, A. Altındağ, Phytoremediation of $\mathrm{Cu}, \mathrm{Cr}$ and $\mathrm{Pb}$ mixtures by Lemna minor, Bull. Environ. Contam. Toxicol., 91 (2013) 600-604.

[159] E. Üçüncü, E, Tunca, S. Fikirdeşici, A. Altındağ, Decrease and increase profile of $\mathrm{Cu}, \mathrm{Cr}$ and $\mathrm{Pb}$ during stable phase of removal by duckweed (Lemna minor L.), Int. J. Phytorem., 15 (2013) 376384.

[160] C. Tang, J. Song, X. Hu, X. Hu, Y. Zhao, B. Li, D. Ou, L. Peng, Exogenous spermidine enhanced $\mathrm{Pb}$ tolerance in Salix matsudana by promoting $\mathrm{Pb}$ accumulation in roots and spermidine, nitric oxide, andantioxidant system levels in leaves, Ecol. Eng., 107 (2017) 41-48.

[161] J. Vymazal, Concentration is not enough to evaluate accumulation of heavy metals and nutrients in plants, Sci. Total Environ., 544 (2016) 495-498.

[162] P. Saha, O. Shinde, S. Sarkar, Phytoremediation of industrial mines wastewater using water hyacinth, Int. J. Phytoremed. 19 (2017) 87-96.

[163] Y. Kara, Bioaccumulation of copper from contaminated wastewater by using Lemna minor, Bull. Environ. Contam. Toxicol., 72 (2004) 467471.

[164] L. Zhang, S. Tian, Z. Ye, H. Peng, The efficiency of heavy metal removal from contaminated water by elsholtzia argi and elsholtzia splendens; Proc. of the international symposium of phytoremediation and ecosystem health, Health J., 10 (2005) 17-28.

[165] S. Mishra, M. Mohanty, C. Pradhan, H.K. Patra, R. Das, S. Sahoo, Physico-chemical assessment of paper mill effluent and its heavy metal remediation using aquatic macrophytes-a case study at JK paper mill, Rayagada, India, Environ. Monit. Assess., 185 (2012) 4347-4359.

[166] J.A. Romero-Hernández A., Amaya-Chávez P. Balderas-Hernández G. Roa-Morales N. González- 
Rivas, M.A. Balderas-Plata, Tolerance and hyperaccumulation of a mixture heavy metals $(\mathrm{Cu}$, $\mathrm{Pb}, \mathrm{Hg}$ and $\mathrm{Zn}$ ) by four aquatic macrophytes, Int $\mathrm{J}$ Phytorem, 19 (2016) 239-245.

[167] R. Othman, R. Ramya, Z.M. Baharuddin, K.S.H. Hashim, M. Yaman, Response of Lemna minor and Salninia natans as phytoremediation agents towards $\mathrm{Fe}, \mathrm{Cu}$ and $\mathrm{Zn}$ toxicities via in vivo model system, J. Teknologi. Sci. Eng., 77 (2015) 101-109.

[168] R. Sallah-Ud-Din, M. Farid, R. Saeed, S. Ali, M. Rizwan, H.M. Tauqeer, S.A.H. Bukhari, Citric acid enhanced the antioxidant defense system and chromium uptake by Lemna minor L. grown in hydroponics under Cr stress, Environ. Sci. Pollut. Res., 24 (2017) 17669-17678,

[169] T.M. Galal, E.M. Eid, M.A. Dakhil, L.M. Hassan,. Bioaccumulation and rhizofilteration potential of Pistia stratiotes L. for mitigating water pollution in the Egyptian wetlands, Int. J. Phytoremediation., 5 (2017) 10-19.

[170] T.M. Galal, F.A. Gharib, S.M. Ghazi, K.H. Mansour, Phytostabilization of heavy metals by the emergent macrophyte Vossia cuspidata (Roxb.) Griff.: a phytoremediation approach, Int. J. Phytoremediation, 19 (2017) 992-999.

[171] I. Panfili, M.L. Bartucca, E. Ballerini, D.D. Buono, Combination of aquatic species and safeners improves the remediation of copper polluted water, Sci. Total. Environ., 601 (2017) 1263-1270.

[172] C. Hu, L. Liu, X. Li, Y. Xu, Z. Ge, Y. Zhao, Effect of graphene oxide on copper stress in Lemna minor L.: evaluating growth, biochemical responses, and nutrient uptake, J. Hazard. Mater., 17 (2017) 30570-30578.

[173] Z. Abbas, F. Arooj, S. Ali, I. E. Zaheer, M. Rizwan, M. A. Riaz, Phytoremediation of landfill leachate waste contaminants through floating bed technique using water hyacinth and water lettuce, Int. J. Phytoremed., 7 (2019) 1-12.

[174] J. Marrugo-Negrete,, , G. Enamorado-Montes, J. Durango-Hernández, J. Pinedo-Hernández, S. Díez, Removal of mercury from gold mine effluents using Limnocharis flava in constructed wetlands, Chemosphere, 167 (2017) 188-192.

[175] R. Zurayk, B. Sukkariyah, R. Baalbaki, D. A. Ghanem, Ni Phytoaccumulation in Mentha Aquatica L. and mentha sylvestris L. Water, Air, and Soil Pollut., 139 (2002) 355-364.

[176] N.R. Axtell, S.P.K. Sternberg, K. Claussen, Lead and nickel removal using microspora and lemna minor, Bioresour. Technol., 89 (2003) 41-48.
[177] S. T. Hussain, T. Mahmood, S. A. Malik, Phytoremediation technologies for $\mathrm{Ni}$ by water hyacinth, African J. Biotech., 9 (2010) 8-23.

[178] S. Pal, H.B. Singh, A. Rakshit, Potential of different crop species for nickel and cadmium phytoremediation in peri-urban areas of Varanasi district (India) with more than twenty years of wastewater irrigation history, Italian J. Agron., 8 (2013) e8.

[179] C. Nevena, D. Vilotic, M. Nesic, M. Veselinovic, D. Drazic, S. Mitrovic, Phytoremediation potential of canna indica $\mathrm{L}$ in water contaminated with lead Fresenius, Environ. Bull., 259 (2016) 3728-3733.

[180] E. Lahive, J. O’Halloran, M.A.K. Jansen, A marriage of convenience; a simple food chain comprised of Lemna minor (L.) and Gammarus pulex (L.) to study the dietary transfer of zinc, Plant Biology, 17 (2013) 75-81.

[181] J. Yang, J. Yang, J. Huang, Role of co-planting and chitosan in Phytoextraction of As and heavy metals by Pteris vittata and castor bean - a field case, Ecol. Eng., 109 (2017) 35-40.

[182] J. Yang, G. Zheng, J. Yang, X. Wan, B. Song, W. Cai, J. Guo, Phytoaccumulation of heavy metals $(\mathrm{Pb}, \mathrm{Zn}$, and $\mathrm{Cd})$ by 10 wetland plant species under different hydrological regimes. Ecol. Eng., 107 (2017) 56-64.

[183] N. Dinh, A.V.D. Ent, D.R. Mulligan, A.V. Nguyen, Zinc and lead accumulation characteristics and in vivo distribution of $\mathrm{Zn}$ in the hyperaccumulator Noccaea caerulescens elucidated with fluorescent probes and laser confocal microscopy, Environ. Exp. Bot., 147 (2018) 1-12.

[184] B.O. Clarke, S.R. Smith, Review of 'emerging' organic contaminants in biosolids and assessment of international research priorities for the agricultural use of biosolids, Environ. Int., 37 (2011) 226-247.

[185] N.S. Thomaidis, A.G. Asimakopoulos, A.A. Bletsou, Emerging contaminants: a tutorial minireview, global NEST J., 14 (2012) 72-79.

[186] M.O.C. Ogwuegbu, C. K. Enenebeaku, C.S.Obi, N. P. Ebosie, C.E. Enyoh, Stoichiometric Determination of $\mathrm{Fe}$ (II), $\mathrm{Ni}$ (II) and $\mathrm{Cu}$ (II) Complexes of Metronidazole, Int. J. Chem. Sci., 3 (2019) 25-29.

[187] M. Qu, N. Li, H. Li, T. Yang, W. Liu, Y. Yan, X. Feng, D. Zhu, Phytoextraction and biodegradation of atrazine by Myriophyllum spicatum and evaluation of bacterial communities involved in atrazine degradation in lake sediment, Chemosphere, 209 (2018) 439-448. 
[188] D.H. Tran, T.M.H. Vi, T.T.H. Dang, R. Narbaitz, Pollutant removal by Canna Generalis in tropical constructed wetlands for domestic wastewater treatment, Global J. Environ. Sci. Manage., 5 (2019) 331-344.

[189] P. Prasertsup, N. Ariyakanon, Removal of Chlorpyrifos by Water Lettuce (Pistia stratiotes L.) and Duckweed (Lemna minor L.), Int J, Phytoremed., 13 (2011) 383-395.

[190] M. Uddin, M. Islam, M. Abedin, Adsorption of phenol from aqueous solution by water hyacinth, ARPN J., Engin. Appl. Sci., 2 (2007) 11-16.

[191] A. L. Seyfferth, M. K. Henderson, D. R. Parker, Effects of common soil anions and $\mathrm{pH}$ on the uptake and accumulation of perchlorate in lettuce, Plant Soil, 302 (2008) 139-148.

[192] J. Wang, X. Liu, X. Zhang, X. Liang, W. Zhang, Growth response and phytoremediation ability of Reed for diesel contaminant, Procedia Environ. Sci., 8 (2011) 68-74.

[193] Zhong G, Wu Z, Yin J, Chai L, 2018. Responses of Hydrilla verticillata (L.f.) Royle and Vallisneria natans (Lour.) Hara to glyphosate exposure, Chemosphere, 193 (2018) 385-393.

[194] S. M. Idris, P. L. Jones, S. A. Salzman, G. Croatto, G. Allinson, Evaluation of the giant reed (Arundo donax) in horizontal subsurface flow wetlands for the treatment of recirculating aquaculture system effluent, Environ.Sci. Pollut. Res., 19 (2011) 11591170.

[195] Ha W., D. L. Suarez, S. M. Lesch, Perchlorate uptake in Spinach as related to perchlorate, nitrate, and chloride concentrations in irrigation water, Environ. Sci. Technol., 45 (2011) 9363-9371.

[196] S. Susarla, S.T. Bacchus, N.L. Wolfe, S.C. Mccutcheon, Phytotransformation of perchlorate and identification of metabolic products in Myriophyllum aquaticum, Int. J. Phytoremed., 1 (1999) 97-107.

[197] T. Machate, H. Noll, H. Behrens, A. Kettrup, Degradation of phenanthrene and hydraulic characteristics in a constructed wetland, Water Res., 31 (1997) 554-560.

[198] A. Priya, K. Avishek, G. Pathak, Assessing the potentials of Lemna minor in the treatment of domestic wastewater at pilot scale, Environ. Monit. Assess., 184 (2012) 4301-4307.

[199] D.D. Yilmaz, H. Akbulut, Effect of circulation on wastewater treatment by Lemna gibba and Lemna minor (floating aquatic macrophytes), Int. J.
Phytorem., 13 (2011) 970-984.

[200] X. Zhao, G.K. Moates, N. Wellner, S.R.A. Collins, M.J. Coleman, K.W. Waldron, Chemical characterisation and analysis of the cell wall polysaccharides of duckweed (Lemna minor), Carbohydr. Polym., 14 (2014) 436-446.

[201] W. Van Echelpoel, P. Boets, P.L.M. Goethals, Functional response (FR) and relative growth rate (RGR) Do not show the known invasiveness of Lemna minuta (Kunth), PLoS, 11 (2016) e0166132.

[202] K.K. Yadav, N. Gupta, V. Kumar, J.K. Singh, Bioremediation of heavy metals from contaminated sites using potential species: a review, Indian J. Environ. Prot., 37 (2017) 65-84.

[203] N.K. Kilic, E. Duygu, G. Dönmez, Triacontanol hormone stimulates population, growth and Brilliant Blue R dye removal by common duckweed from culture media, J. Hazard. Mater., 182 (2010) 525-530.

[204] D.A. Yaseen, M. Scholz, Comparison of experimental ponds for the treatment of dye wastewater under controlled and semi-natural conditions, Environ. Sci. Pollut. Res. Int., 24 (2017) 16031-16040.

[205] E. Neag, D. Malschi,, A. Măicăneanu, Isotherm and kinetic modelling of toluidine blue (TB) removal from aqueous solution using Lemna minor, Int. J. Phytorem., 20 (2018) 1049-1054.

[206] Souza, T. D. de, Borges, A. C., Matos, A. T. de, Veloso, R. W., \& Braga, A. F. (2018). Kinetics of arsenic absorption by the species Eichhornia crassipes and Lemna valdiviana under optimized conditions, Chemosphere, 209 (2018) 866-874.

[207]A.W. Verla, E. N. Verla, C. E. Enyoh, Chemometrics in environmental analytical chemistry: A review of mathematical models and their applications. Proceedings of $3^{\text {rd }}$ world environment day conference, Imo State University, Nigeria, 16, 2019.

[208] A.W. Verla, E.N. Verla, C.M. Ajero, K.C. Lele, N.O. Stellamarris, C.E. Enyoh, Biomonitoring of heavy metals in blood and urine of African children from Owerri Metropolis, Eastern Nigeria, J. Chem. Health Risk., 9 (2019) 11-26.

[209] A.W. Verla, C.E. Enyoh, V.E. Ngozi, P.N. Okeke, S.S. Pingale, Chemometric assessment of orashi river after confluence with oguta lake, Indonesian J. Fundamental Appl. Chem., (2019). Accepted manuscript.

[210] M.S. Islam, T. Saito, M. Kurasaki, Phytofiltration 
of arsenic and cadmium by using an aquatic plant, micranthemum umbrosum: phytotoxicity, uptake kinetics, and mechanism, Ecotoxicol. Environ. Safe., 112 (2015) 193-200.

[211] M. Srivastava, L.Q. Ma, N. Singh, S. Singh, Antioxidant responses of hyperaccumulator and sensitive fern species to arsenic, J. Exp. Bot., 56 (2005) 1335-1342.

[212] R.A. Fisher, Some remarks on the methods formulated in a recent article on 'The quantitative analysis of plant growth, Ann. Appl. Biol., 7 (1921) 367-372.

[213] D.A. Wilkins, The measurement of tolerance to edaphic factors by means of root growth, New Phytol., 80 (1978) 623-633.

[214] J.A. Romero-Hernández, A. Amaya-Chávez, P. Balderas-Hernández, G. Roa-Morales, N. González-Rivas, M.A. Balderas-Plata, Tolerance and hyperaccumulation of a mixture heavy metals $(\mathrm{Cu}, \mathrm{Pb}, \mathrm{Hg}$ and $\mathrm{Zn}$ ) by four aquatic macrophytes, Int. J. Phytorem., 19 (2016) 239-245.

[215] V. Vadivelan, K.V. Kumar, Equilibrium, kinetics, mechanism, and process design for the sorption of methylene blue onto rice husk, J. Colloid Interface Sci., 286 (2005) 90-100.

[216] A.W. Verla, M. Horsfall (Jnr), E.N Verla, A.I. Spiff, Some aspect of surface chemistry of activated carbon prepared from fluted pumpkin (Telfairia occidentalis Hook. F.) by physical activation, Int. J. Chem. Sci. Technol., 2 (2012) 224-230.

[217] B. O. Isiuku, C. N. Nwosu, Fixed-bed adsorption of metanil yellow from aqueous solution on $\mathrm{HNO}_{3}$ treated- $\mathrm{H}_{3} \mathrm{PO}_{4}$-activated carbon frm gmelina bark, Asian J. Chem., 29 (2017) 475-479.

[218] F. Zurita, J. De Anda, M.A. Belmont, Treatment of domestic wastewater and production of commercial flowers in vertical and horizontal subsurface-flow constructed wetlands, Ecol. Eng., 35 (2009) 861869.

[219] O. C. Türker, A. Yakar, N. Gür. Bioaccumulation and toxicity assessment of irrigation water contaminated with boron (B) using duckweed (Lemna gibba L.) in a batch reactor system, J.Hazard. Mater., 324 (2017) 151-159.

[220] Y.H. Su, Y.G. Zhu, Transport mechanisms for the uptake of organic compounds by rice (Oryza sativa) roots, Environ. Pollut., 148 (2007) 94-100.

[221] V.A. Wirnkor, E.C. Ebere, V.E. Ngozi, N.K. Oharley, Microplastic-toxic chemical interaction: A review study on quantified levels, mechanism and implication, SN Appl. Sci., (2019). https://10.1007/ s42452-019-1352-0

[222] A. A. Romeh, Phytoremediation of cyanophos insecticide by Plantago major L. in water, J. Environ. Health Sci. Eng., 12 (2014) 38.

[223] M. Michel, B. Buszewski, HPLC determination of pesticide residue isolated from food matrices, J. Liq. Chromatogr. Related Technol., 25 (2002) 2293-2306.

[224] C. Ferrer, M.J. Gomez, J.F. Garcı-Reyes, I. Ferrer, Determination of pesticide residues in olives and olive oil by matrix solid-phase dispersion followed by gas chromatography/mass spectrometry and liquid chromatography/tandem mass spectrometry, J. Chromatogr. A, 1069 (2005) 183-194.

[225] C. Tsoutsi, C. I. Konstantinou, D. Hela, T. Albanis, Screening method for organophosphorus insecticides and their metabolites in olive oil samples based on headspace solid-phase microextraction coupled with gas chromatography, Anal. Chim. Acta, 573 (2006) 216- 222.

[226] N. Chamkasem, L.W. Ollis, T. Harmon, S. Lee, G. Mercer, Analysis of 136 Pesticides in Avocado Using a Modified QuEChERS Method with LCMS/MS and GC-MS/MS, J. Agric. Food Chem., 61 (2013) 315-2329. 